\title{
EFEITO DO NÚMERO DE BROTOS E DA FERTILIZAÇÃO MINERAL SOBRE O CRESCIMENTO DA BROTAÇÃO DE 己uaalyptus saligna SMITH, EM SEGUNDA ROTAÇÃO
}

\author{
NORMAN ALEXIS SABILLÓN COTO \\ Engenheiro Florestal \\ Universidad Nacional Autónoma de Honduras \\ - C. U. R. L. A. -
}

Orientador: Prof. Dr. JOĀO WALTER SIMŌES

\begin{abstract}
Dissertação apresentada à Escola Superior de Agricultura "Luiz de Queiroz", da Universidade de São Paulo, para obtenção do título de Mestre em Engenharia Florestal.
\end{abstract}

PIRACICABA

Estado de São Paulo - Brasil

Novembro - 1985 
Dedico:

Aos meus. pais:
J̣utio Sabittón Pineda (in memorian)
Mercedes Coto de Sabillón
A minha esposa Gioco e aos meus filhos Willberto e Gustavo.
Aos meus irmãos Eduardo, Juiio, German, Joaquin, Arcadolina e Guadalupe.




\section{AGRADECIMENTOS}

- Ao Prof. Dir. João Walter Simões, pela orientação precisa durante a elaboração deste trabalho.

- Ao Prof. Dr. Hilton Tadeu Zarate do Couto pelas sugestões na realização deste trabalho.

- Ao Prof. Dr. Luiz Ernesto George Barrichello, pelas sugestões e apoio nas análises da densidade da madeira.

- A Durafịora Silvicultura e Comércio Ltda., pela instalacão, condução do experimento e apoio no levantamento dos dados.

- Ao Engo Florestal Fernando Patiño-Valera, pelas sugestões e apoio na elaboração deste trabalho.

- Ao Engo Agro Juan Medina Pitalúa pelas sugestões a apoio 0 ferecidas.

- Ao Enge florestal fábio Spina-França pela colaboracão e su gestões oferecidas.

- Ao Engo Agro Pedro Alvarenga A., pelo apoio oferecido. 
- Ao Instituto de Pesquisas e Estudos Florestais; pela cessão dos dados do experimento e das anâlises estatísticas.

- Ao Sr. Jair Augusto Diehl pela dedicação e eficiência na a nälise estatistica dos dados.

- A Srạ Maria Alice Metzker Poggiani, por seu apoio ña procü - ra da informação citada no trabalho.

- A Universidad Nacional Autōnoma de Honduras pelos subsîdios, atrávés de bolsas de Estudo, para a realização do Curso de Pós-Graduação e deste trabalho.

- A todo pessoal docente, administrativo, funcionārios e estagiārios do Departamento de Silvicultura, que de uma forma ou de outra, concorreram para a realização deste traba1ho. 


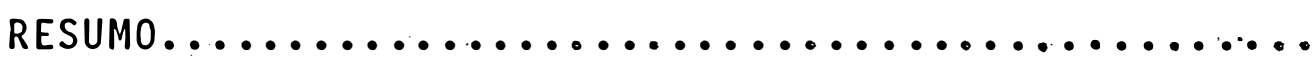

1. INTRODUÇÃO......................... 1

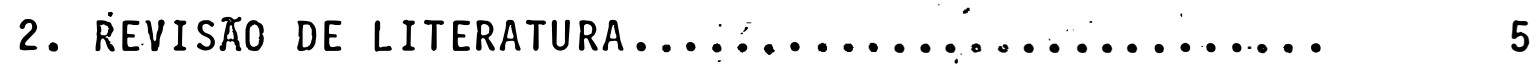

2.1. Conducão da brotação................ 5

2.2. Fertilização floresta1............... 19

2.2.1. Fertilização em primeira rotação....

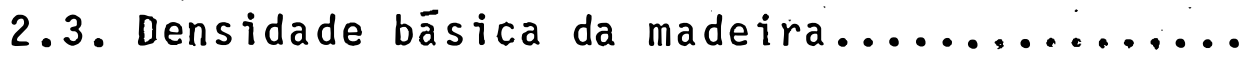

2.3.1. Variação da denșidade da madeira com as taxas de crescimento............

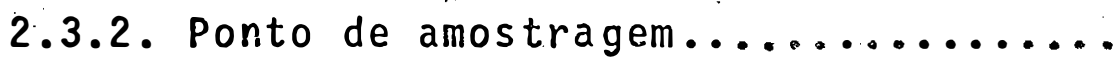

3. MATERIAL E METODOS..................... 23

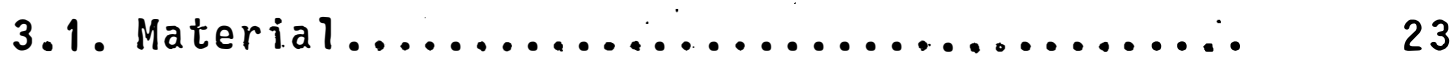

3.1.1. Localização.................. 23

3.1.2. Espëcie................... 23

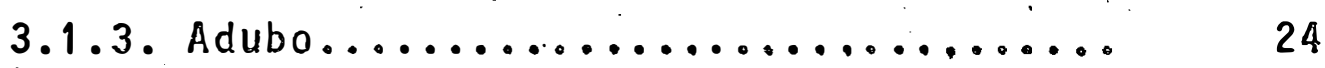

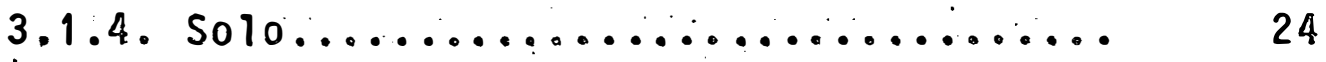

3.1.5. Crima........................... 25

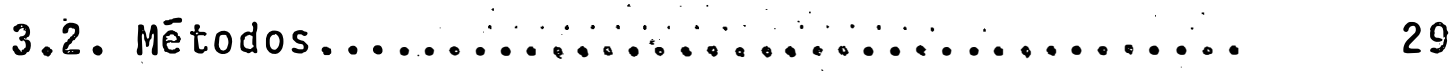

3.2.1. Delineamento experimental........ 29 
3.2.2. Desbrota................... 30 .

3.2.3. Adubação................... 30

3.2.4. Avaliações dendrométricas da brota.

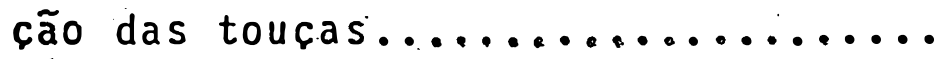

3.2.5. Cálculo da altura média e diâmetro

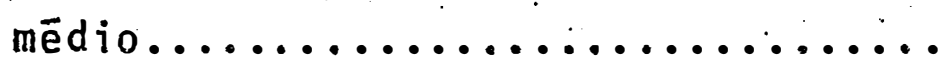

3.2.6. Cậlculo da ārea basal média por hec-

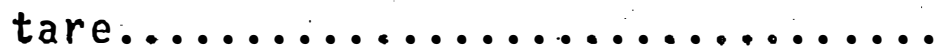

3.2.7. Cálculo do volume ciliñndrico........

3.2.8. Anāilise estatística dos dados de cres

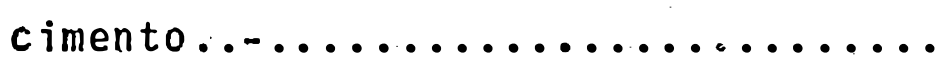

3.2.9. Amostragem para a determinacão dos pa râmetros dendromētricos............

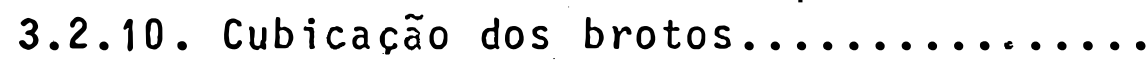

3.2.11. Cálculo do fator de forma...........

3.2. $\{2$. Cálculo da porcentagem de casca....

3.2.13. Cálculo do fator de empilhamento....

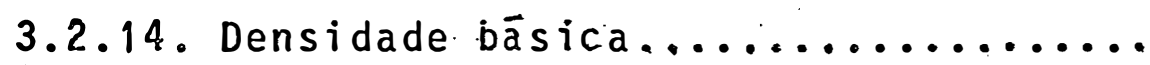

3.2.15. Corte final do experimento.........

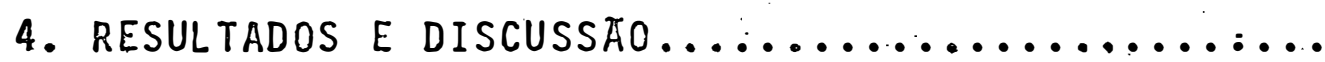

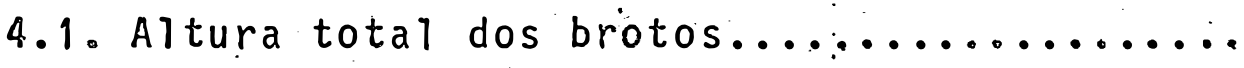

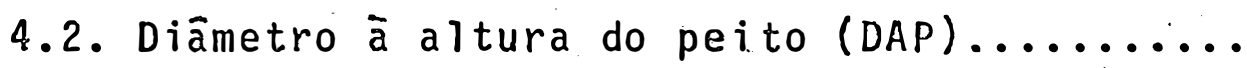

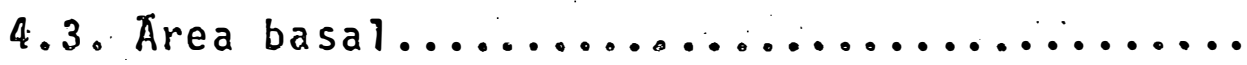


.vii.

Pāgina

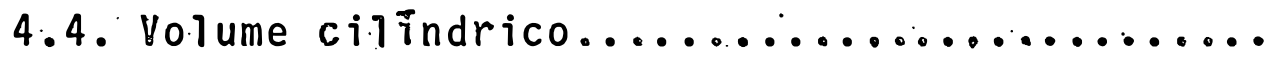

4.5. Sobrevivência $\ldots \ldots \ldots \ldots \ldots \ldots \ldots \ldots \ldots$

4.6. Anālise de covariância do DAP, altura e volü

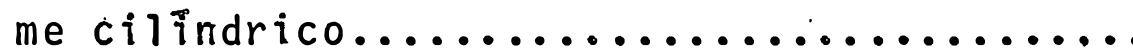

4.7. Fatores de forma e de empilhamento.........

4.8. Densidade básica, porcentagem de casca, volu me de madeira empilhada e peso de madeira se ca.

5. CONCLUSÕES

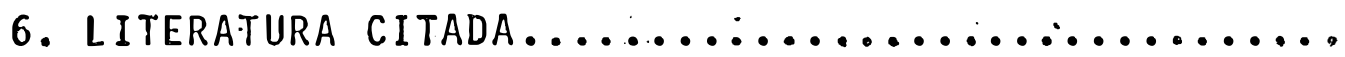

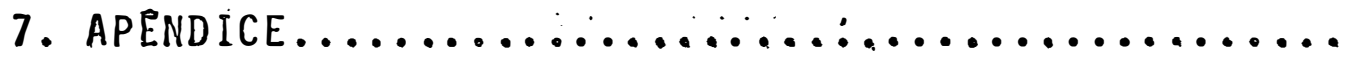




\section{EFEITO DO NÚMERO DE BROTOS E DA FERTILIZACÃO MINERAL SOBRE O CRESCIPGENTO DA BROTACÃO DE Eucalyptus saligna SMITH, EM SEGUNDA ROTACÃO}

Autor: NORMAN ALEXIS SABILLONN COTO

Orientador: Prof. Dr, JOAO WALTER SITMOES

\section{RESUPHO}

0 presente trabalho foi desenvolvido com os ob jetivos de estudar o efeito da fertilização mineral sobre o crescimento da brotação, verificar qual o nūmero de brotos que propicia o maior volume de madeira utilizável para chapas de fibras e determinar atravēs da den sidade básica o efeito dos tratamentos sobre a produção em, peso de màde ra.

0 ensaio foi instalado em 1978, no espacamento $3,0 \times 1,5 \mathrm{~m}^{2}$ e obedeceu a um esquema fatorial $4 \times 2$, com 8 tra tamentos e 3 repetições. As parcelas foram constituîidas de 49 plantas isoladas por uma bordadura dupla, fazendo com que 0 experimento ocupasse uma área total de $13.068 \mathrm{~m}^{2}$.

Foram aplicados $300 \mathrm{~g}$ de NPK da fórmula 10-28-6

+ B e Zn à base de $3 \mathrm{~g}$ de sulfato de zinco e $2 \mathrm{~g}$ de börax por planta. Foram, ainda, coletadas amostras de solo: A desbrota fo $i$ efetuada (16 meses) apōs o corte raso. 
0 experimento foi avaliado com 18, 29, 52, 64, 76 e 85 meses de idade da brotação, onde foi medido o crescimento em DAP e altura, bem como, a porcentagem de falhas. Aos 85 meses foi feita a avaliação final, quando foram amostradas as touças para determinação da porcen tagem de casca, fator de forma, o fator de empilhamento das hastes das touças e foram retirados discos no DAP para determinação da densidade da madeira. Em seguida foi feito o corte raso e a medição do volume final de madeira empilhada, com casca, por tratamento.

Anālises estatisticas dos dados do experimento foram realizadas para DAP, altura, volume cilindrico e porcen tagem de falhas, para todas as épocas de medição, como tambēm para densidade básica, produção volumétrica de madeira empilhada após o corte final do experimento e produção em peso de madeira seca.

Da discussão dos resultados, foram tiradas ãs seguintes conclusões, resumidas a seguir:

- A fertilização e o número de brotos por touca influenciaram o crescimento em altura e em DAP das brotações:

- 0 nümero de brotos por touça influenciou diretamente na expressão da ārea basal.

- A fertilização influenciou o crescimento em ārea basal, como tambēm, o volume cilīndrico. 
- A sobrevivência das cepas e a densidade básica da madeira foram afetadas pelo número de brotos nem pela fertilização.

- Os três melhores tratamentos em produção de madeira empilha da foram os seguintes: T8 ( 3 brotos, com adubação), T2 (sem desbrota, com adubação) e T6 ( 2 brotos, com adubação) com 394,$78 ; 317,74$ e 283,26 esteres/ha, respectivamente. 0 pior tratamento foi com 1 broto, sem adubação.

- A produção em peso de madeira seca na segunda rotação não foi influenciada significativamente pela adubação e pelo nū mero de brotos por touça. Entretanto, os tratamentos com maior número de brotos e com adubação estão acima da média que foi de 105,51 t/ha. A maior produção foi obtida no tratamento T8 ( 3 brotos, com adubação) com 144,44 t/ha e a menor no T3 ( 1 broto, sem adubação) com 82,19 t/ha de matéria seca. 


\section{THE EFFECT OF NURBER OF SPROUTS AND OF MINERAL FERTILIZATION ON THE GROWTH OF SPROUTS OF Eucalyptus saligna SMITH IN THE SECOND ROTATION}

Author: NORMAN ALEXIS SABIILLON COTO

Adviser: Prof. Dr. JOAO WALTER SIMOES

The objectives of this work were to study the effects of mineral fertilization on sprout growth, to determine the number of sprouts that would yield greater wood volume to produce fiber board, and to determine through the wood basic density the effects of the treatments on the production of the wood weight

The trial was established in a stand with spacement of $3.0 \times 1.5 \mathrm{~m}$ between rows and plants, at the Fazenda Rio Claro in Lençōis Paulista (SP) in 1978.

A factorial design $4 \times 2$ with 8 treatments and 3 replications was utilized. The plots consisted of 49 plants with double borders, and occupied an area of $13,068 \mathrm{~m}^{2}$. The treatments were one, two and three sprouts per stumps and coppice without thining and with or without mineral fertilization. The fertilization, $300 \mathrm{~g}$ NPK $(10-28-6)$ plus $B$ (2 g borax per plant) and $\mathrm{Zn}$ ( $3 \mathrm{~g}$ of zinc sulphate per plant) 
was top dressed and incorporate.

Evaluations for $D B H$, height growth and stump survival were made at $18,29,52,64,72$ and 8,5 months of age after clear-cutting. In the evaluation made at 85 months of age, the bark form factor and the bark porcentage of the sprouts, the piling factor with bark.

The final volume of piled wood with bark and sampling for wood specific gravity and the soil for each treatment were determined.

The analysis of the results allowed the following conclusions:

a) The fertilization and the number of sprouts per stumps influenced the height and DBH growth of the sprouis.

b) The number of sprouts per stump had a direct influence on the expression of the basal area.

c) The fertilization influenced the basal area growth and the cylindric volume.

d) The stump survival and wood specific gravity-were not altered by the number of sprouts nor by the fertilization. 
e) The three best treatments for wood production were: three sprouts per stump plus fertilization ( 394.78 st); coppice without management plus fertilization (394.78 st) and two sprouts per stumps plus fertilization (283.26 st). The worst treatment for wood production was one sprout per stump without fertilization.

f) The dry weight of the wood produced in the second rotation was not significantely effected by the number of sprouts nor by fertilization. However, the treatments with a larger number of sprouts and with fertilization are above the average of $105.51 \mathrm{t} / \mathrm{ha}$. The higher wood weight was produced by the treatment with three sprouts per stumps plus fertilization (144.44 t/ha) and the lowest wood weight was produced by the treatment with one sprout per stump without fertilization (82.19.t/ha). 
EFECTO DEL NUMERO DE BROTES Y DE LA

FERTILIEACION MINERAL SOBRE EL CRECIMIENTO DE LA BROTACION DE Eucalyptus saligna SMITH, ER SEGUNDA ROTACION

Autor: NORMAN ALEXIS SABILLON COTO

Orientador: Prof. Dr. JOAOO WALTER SIMŌES

\section{RESUMER}

El presente trabajo fue desarrollado con los objetivos de estudiar el efecto de la feritilización mineral sobre el crecimiento de la brotación, verificar cuāi es el número de brotos que propicia el mayor volumen de madera utilizable para chapas de fibras y determinar a travēs de la densidad básica el efecto de los tratamientos sobre la pro ducciōn en peso de madera.

E1 ensayo fue instalado em 1978 con un espacia miento de $3,0 \times 1,5 \mathrm{~m}$ y obedeció a un esquema factorial $4 \times 2$ con 8 tratamientos y 3 repeticiones. Las parcelas fueron cons tituidas de 49 plantas aisladas por una doble bordadura haciendo, con que el experimento, ocupase una área total de $13.068 \mathrm{~m}^{2}$.

Fueron aplicados $300 \mathrm{~g}$ de NPK de 1 a fórmula $10-28-6+B$ y $\mathrm{Zn}$, a base de $3 \mathrm{~g}$ de sulfato de zinc y $2 \mathrm{~g}$ de boraxpor planta.

E. experimento fue evaluado con $18,29,52,64$, 
76 y 85 meses de edad de la brotación, donde fue medido el crecimiento en DAP y altura, como.tambiēn el porcentage de fallas. A los 85 meses fue hécha la evaluación final cuando fueron muestradas las cepas para la determinación del porcentage de cásciara, factor de forma, factor de empilamiento. de los brotes de las cepas y tambiēn fueron retirados discos en el DAP para la caracterización de la densidad de la madera. Ademās, fueron colectadas muestras de suelo en el lugar del experimento. En seguida fué realizado el corte raso y la mediciōn del volumen final de madera empilada con cāscara, por tratamiento. Los anāicis estadísticos de los datos de crecí miento fueron realizados para DAP, altura, volumen cilindrico y porcentage de fallas, para todas las épocas de medición, como tambiēn para densidad básica, producciōn volumétrica de. madera empilada, después del corte final del experimento y producción en peso de madera seca.

De la discusión de los resultados se sacaron las siguintes conclusiones; resumidas a seguir:

1. La fertilizaciōn y el número de brotes por cepa influyeron el crecimiento en altura y en DAP de las brotaciones.

2. 'El nūmero de brotes por cepa influyó directamente en la ex presiōn del área basal. 
3. La fertilización influyō el crecimiento en ārea basal, como tambiēn el volumen ciłiñndrico.

4. La sobrevivencia de las cepas y la densidad básica de la madera no fueron afectadas por el nümero de brotes, ni por la fertilización.

5. Los tres mejores tratamientos en producción de madera empi Tada fueron los siguiences: 8 ( 3 brotes, con fertilizante), 2 (sin desbrote, con fertilizante) y 6 (2 brotes con ferti lizante) con 394,$78 ; 317,74$ y 283,26 estēreos/ha respectivamente: El peor tratamiento fue 3 (1 brote sin fertilizan te).

6. La producción en peso de madera seca en la segunda rotación no fue influenciada significativamente por la fertili zaciōn nipor el nümero de brotes por cepa. Mientras los tratamientos con mayor nūmero de brotes y con fertilizante e tān arriba de la media que es de 105,51 t/ha. La mayor producción fue obtenida en el tratamiento 8 ( 3 brotes con fer tilizante) con 144,44 t/ha y la menor en el 3 ( 1 brote sin fertilizante) con $82,19 \mathrm{t} / \mathrm{ha}$ de madera secia. 


\section{IUTRODUCÃO}

O tremendo incremento na demanda de madeira, oriundo do desenvolvimento econômico e industrial, provocou uma revolução nas técnicas florestais. Como consequéncia, a atuai silvicultura baseia-se no cultivo intensivo das flores tas, objetivando produzir a maior quantidade de madeira, no menor tempo e ao menor custo, e com as características adequadas para a sua utilização.

O Brasil dispõe atualmente, de extensas areas de florestas implantadas. com espëcies dos gēneros Eucalyptus e Pinus. Segundo dados do IBDF, ate 1983, foram reflorestados no Brasil, atravēs dos incentivos fiscais, um total de 4,7 milhões de hectares, dos quais 2,53. milhões com Eucalyptus, 1,43 milhões de hectares com Pinus, $45 \mathrm{mil}$ hectares com Arau caria e 620 hectares com essências nativas diversas. 
O destino da madeira produzida nessas florestas, segundo o IBDF, citado por S.ILVA (1984), serā o seguin te: papel e celulose 1,38 milhões de hectares (37\%); energia 1,36 milhões de hectares $(32,2 \%)$; madeira processada mecani camente 714 mil hectares $(16,9 \%)$ e 771 mil hectares (18.2\%) destinados a outros fins.

E importante salientar que a maior superficie de povoamentos foi estabelecida utilizando-se Eucalyptus gran dis, E. saligna e $E$. urophylla, e, mais recentemente, estão sendo utilizadas outras espēcies, principalmente para produ çao de carvao vegetal.

E inegāvel que as prāticas silviculturais no Brasil vêm mostrando uma evolução muito grande nos ūitimos $\underline{a}$ nos. A tomada de consciência quanto a importância da escolha de sementes melhoradas, adubações corretas, espaçamentos adequados, manejos silviculturais voltados para a mäxima pro dução, e muitas proposições novas e idéias ousadas, resultaram em dobrar a produtividade nos povoamentos das grandes em presas florestais, o que, segundo a FAO (1981).: para Eucalyp tus grandis e E. saligna è de $30 \mathrm{~m}^{3} / \mathrm{ha} / \mathrm{ano}$ ou ainda maior.

A união da indústria com as universidades e institutos de pesquisa, conscientemente organizados, com tra balhos eficientes e realistas, consolidou-se e logrou o desenvolvimento e adoção de novas tecnologias, com uma conse quente acumulação de experiências e estimulos parạ um contí nuo aperfeicoamento. Isso fez com que o Brasil já disponha de tec- 
nologias nacionais de vanguarda, dando um imenso para para a sua independência tecnológica neste setor.

O estudo da fertilização mineral em frorestas é relativamente recente, sendo que os primeiros ensaios foram conduzidos na França, por volta de 1847, obtendo-se ga nhos apreciāveis no desenvolvimento, das ārvores (BAULE e FRIC KER, 1970). Após 1930, tiveram início os primeiros estudos sobre fertilização em florestas nos. Estados Unidos, com a ins talação de alguns ensaios de campo na região sul do pafs (Benston, 1968, citado por BEATON, 1973).

As espēcies do gēnero Eucalyptus apresentam a propriedade de brotarem após o corte realizado na floresta, produzindo, posteriormente, volumes de madeira muito semeThantes aos do primeiro corte.

A necessidade de garantir a rebrota dos euca liptos em segunda rotação, através de prāticas silviculturais adequadas, foi razão suficiente para suporitar a realiza ção de pesquisas para definir os futuros programas de implan tação florestal, principalmente em regiões com condiçöes cli máticas e edáficas que interferem negativamente na produtị $\underline{i}$ dade desses novoamentos.

Algumas florestas, por ocasião do segundo cor te apreseritam acentuada queda na produção, devido à baixa percentagem de regeneração e/ou ao péssimo desenvolvimento dos brotos. o aproveitamento do povoamento para nova exploração, através da condução da brotação se deve ao fató de evitar no 
vo plantio (HAAG et alii, 1983). A regeneraçao de brotos apresenta crescimento mais räpido do que plantio por mudas, di minuindo a rotação (NAVARRO DE ANDRADE, 1961).

A condução dessa brotação tem sido objeto de inumeros trabalhos de pesquisa, visando analisar o efeito da condução, a desbrota, os custos associados e a influência da fertilização mineral na sua produtividade.

Desse modo, torna-se imprescindivel o melhor conhecimento das necessidades nutricionais e seus efeitos, ao serem aplicadas diversas técnicas silviculturais às espe cies de Eucalyptus.

0 presente trabalho tem os seguintes objetivos: Estudar o efeito da fertilização mineral sobre o crescimento da brotação.

Verificar qual o numero de brotos que propicia o maior volume de madeira utilizável para chapas de fibras.

- Determinar através da densidade básica o efeito dos tratamentos sobre a producão em peso de madeira. 


\section{REVISÃO DE LITERATURA}

\subsection{CONDUÇÃO DA BROTAÇÃO}

Nas espécies florestais como os eucaliptos, ca pazes de brotar, a regeneração após o corte raso se faz por brotação das touças (SIMÕES, 1978). Acrescenta que a possibi lidade econômica de manter a brotação para novo corte depende da produtividade volumétrica esperada. Está, por sua vez, tende a se reduzir gradativamente à medida que diminui a sobrevivência das touças pela sucessão dos cortes.

Segundo SIMOES et alii (1981), a desbrota con siste na redução de número de brotos por cepa, que deve ser feita sempre que houver um nümero excessivo deles, proceden do-se a uma seleção e mantendo somente os brotos mais vigoro sos e bem implantados. Usualimente mantēm-se 2 a 3 brotos por cepa em função do objetivo do uso da madeira e da quantidade 
de falhas, visando recuperar a população para garantir e man ter a alta produtividade por unidade de ārea na rotação seguinte. Hā empresas que estão mantendo um nümero de brotos com base no diâmetro da cepa e de seu posicionamento no ta1hão. Nas cepas com diāmetro menor ou igual a $8 \mathrm{~cm}$ será man tido 1 só broto, ao passo que nas maiores de $8 \mathrm{~cm}$ serão man tidos 2 ou 3 brotos, dependendo da sua posiçäo no talhão. Quan do a cepa estiver na bordadura do talhão ou prōxima a falhas serão mantidos 3 brotos, no ćaso contrārio, serão mantidos so mente 2 .

BARRET et alii (1975) sugeriram que a prätica de desbrota geralmente deve ser feita para reduzir o nümero de brotos para 2 ou 3 por touça, quando a altura média da plantação estiver com $4 \mathrm{~m}$. Deve-se fazer nova desbrota um ano apōs, deixando-se 1 ou 2 brotos favorecendo-se um broto para produção de melhores postes e 2 brotos para os outros tipos de materiais. Eles posteriormente defenderam que o nūmero eventual de fustes que permanecem depois da limpeza nẵ deve ser menor que o número de mudas originalmente plantadas.

BALLONI et alii (1978), trabaihando na condu ção de touças de Eucalyptus, com 1, 2 e 3 brotos por touça, concluirram que o maior rendimento em volume foi propiciado por 2 brotos por touça, tanto em Sorocaba como em salesōpolis, S.P.. 
Estudando a influência sobre a produtividade da condução da brotação com três diferentes alturas de corte $(15,30,40 \mathrm{~cm})$ e 4 diferentes nūmeros de brotos por cepa (1, 2 , 3 e 4 brotos), em uma floresta de Eucalyptus urophulla, tanto no primeiro como no segundo corte, MENDES et alii (1980) concluíram que à idade de 2 anos o número de brotos in fluenciou significativamente o crescimento em diâmetro e em volume no segundo corte.

- PEREIRA et alii (1980), analisando o número ó timo de brotos por cepa de Eucalyptus urophylla, que deve ser deixado por ocasião da desbrota, concluiram que a ārea basal aumentou com o aumento do nūmero de brotos por cepa, atē 4 brotos. A partir dai, o aumento do nūmero de brotos influen cia negativamente a área basal, acontecendo o mesmo com o vo lume. De acordo com os estudos realizados, 4 brotos por cepa è o nūmero tecnicamente recomendāvel, pois contribui para que haja $33 \%$ de elevação do volume em comparação com as parcelas sem desbrota.

Entretanto, em reḷação ao nūmero de brotos por touça, REZENDE et alii (1980) verificaram que quanto maior for o número de brotos, maior será o crescimento em altura e voíume, tanto após o primeiro como no segundo corte (Tabela 1). 
Tabela 1 - Crescimento em altura e produção volumētrica em função do nū mero de brotos por cepa, para Eucalypus alba.

\begin{tabular}{|c|c|c|c|c|}
\hline \multirow{2}{*}{$\begin{array}{l}\text { NO DE BROTOS } \\
\text { POR CEPA }\end{array}$} & \multicolumn{2}{|c|}{ 10 CORTE* } & \multicolumn{2}{|c|}{ 29 CORTE** } \\
\hline & $H(m)$ & Vol. $\left(\mathrm{m}^{3} / \mathrm{ha}\right)$ & $H(m)$ & Vol. $\left(\mathrm{m}^{3} / \mathrm{ha}\right)$ \\
\hline 1 & 5,17 & 5,130 & 5,25 & 4,609 \\
\hline 2 & 5,47 & 10,130 & 5,32 & 4,484 \\
\hline 3 & 5,47 & 13,070 & 5,06 & 8,677 \\
\hline 4 & 5,93 & 17,700 & 5,12 & 11,351 \\
\hline
\end{tabular}

Fonte: REZENDE et alii (1980).

* Avaliação 1 ano apōs o 10 corte.

** Avaliação 1 ano apōs 02 ? corte.

TUSET (1981), estudando a brotação de algumas espécies florestais, recomenda deixar crescer livremente os brotos durante uma a duas temporadas de desenvolvimento e de pois efetuar a desbrota, deixando de 2 a 4 brotos por cepa. os melhores em altura, diâmetro e retidão e se tiver boas con dições de mercado para diâmetros maiores, seria conveniente u ma nova desbrota para deixar 1 a 2 brotos por cepa, depois do 39 ou 40 ano.

Têcnicos da F́ (1981) recomendam que se o ob jetivo da condução da brotação é produzir fustes mais retos e de maior valor, a desbrota tem que ser feita deixandose. 3 ou 2 brotos por cepa ou. deixar só um, e comentam que quanto mais brotos se deixem em um cepa, tanto menore's serão 
seus diāmetros finais. No entanto, mais brotos podem produzir mais volume em rotações mais curtas. Mas, o valor poten cial do material produzido por um broto por cepa, , reto, bem selecionados, será possivelmente superior.

PEREIRA e LADEIRA (1983). estudaram os custos de desbrota efetuada aos.5, 10 e. 15 meses de idade, deixando-se em cada cepa $1,2,3,4$ e todos os brotos. De acordo com os resultados dos custos da desbrota, associados com. o volume de madeira obtido aos 42 meses de idade, $r$ recomendam deixar o maior nūmero de brotos possível por cepa, eliminando apenas os dominados quando se pretende utilizar a madeira para a produção de carvão vegetal. No caso de madeira para serraria, deixar um broto por cepa em rotações mais longas.

PAIVA et alii (1983), estudando a influēncia da idade de corte, da idade de desbrota e do nümero de brotos por cepa sobre o desenvolvimento em altura, em DAP e em área basal por hectare, e sobre a sobrevivencia das cepas de Eucalyptus spp., concluĩram que: a idade de desbrotanão afetou nenhum dos parāmetros avaliados. Entretanto, a idade de corte afetou os diāmetros dos brotos e a sobrevivência das cepas. 0 nümero de brotos por cepa influenciou significativa mente O DAP, a altura e a ārea basal por hectare, com baixa influēncia sobre a sobrevivenncia das cepas. Assim, pelos re sultados obtidos, a quantidade de brotos a ser deixada apös o corte irā depender da utilização futura da matéria prima, 
recomendando-se näo fazer a desbrota se a utilizą̧ão futura for a produção de carvão vegetal, lenha ou celulose.

Por sua vez, POYNTON (1983) relata que gera! imente ē aceito que repetidas explorações de um povoamento, $\underline{a}$ través do regime de talhadia, conduzem a uma diminuição do volume produzido. Esse fato é devido a uma diminuição no cres cimento do povoamento, através da mortalidade das touças mais que ao debilitamento das touçás ou empobrecimento do solo.

Van Laar (1961), citado por POYNTON (1983), in dicou que para Eucalyptus grandis, os crescimentos em altura (e consequentemente a classede "site") não mostraram mudan ças progressivas com rebrotaçōes'repetitivas. Em "sites" médios, pode-se obter pelo menos duas colheitas antes de que sejam necessários o replantio ou interplantio, desde que a dade das árvores, na época do corte, não exceda os 10 a 12 a nos.

Stubbings e Schönau (1979), citados por POY TON (1983), recomendam que a desbrota em Eucalyptus grandis deve ser feita quando a altura dominante da plantação estiver entre 3 e $4 \mathrm{~m}$. Deve ser executada em pelo menos duas etapas: a primeira, deixando de 2 a 3 brotos por touça (dependendo do objetivo do manejo) e a segunda, quando a altura dos brotos estiver entre 7 a $8 \mathrm{~m}$, deixando-se 1 ou 2 brotos por tou ça. 


\subsection{FertilizaçÃ̃o FLOREstal}

o objetivo da fertilização florestal contempo rānea é encontrar um equilíbrio nas doses dos elementos necessários ao crescimento das plantas, para evitar perdas el ou excesso no balanço dos elementos minerais.

\subsubsection{FERTILIZAÇÃO EM PRIMEIRA ROTAÇÃO}

Segundo BARROS (1982), a adubação é atualmen te uma técnica silvicultural amplamente aceita e empregada com o objetivo de aumentar a produtividade dos plantios florestais. Entretanto, a efetividade da adubação depende de $\underline{u}$ ma sērie de fatores, tais como:

a) seleção das fontes de nutrientes mais apro priadas para cada situação em particular, com base na espēcie florestal, nas caracteristicas do solo, nas condições e cológicas e particularidades econômicas;

b) aplicação do material na forma e maneira que maximizem seu potencial como fonte de nutrientes, ao mes mo tempo que minimizem os custos e problemas associados ao seu uso.

SIMOEES E SPINA-FRANÇA (1983) indicaram que os estudos sobre fertilização florestal no Brasil são relativamente recentes. Dentre os primeiros trabalhos desenvolvidos destacam-se os de BRASIL SOBRINHO et alii (1963) e MELLO et 
alii (1970), os quais assentaram as bases para determinar as formulações a se utilizar nos povoamentos de eucaliptos no Brasil.

MELLO et alii (1970) comentam que o uso de fer tilizantes minerais justifica-se pelos resultados obtidos em nosso meio, onde pode ser encarado como elemento fundamental no sucesso do plantio em áreas pouco favoráveis do ponto de vista da riqueza mineral do sol.o. Acrescentam que as florestas implantadas só poderão sér realmente econômicas se, às prāticas normais de plantio e condução, for acrescentado o emprego de fertilizantes minerais.

A partir da década de 1970, foram desenvolvidas inümeras pesquisas visando o conhecimento das necessida des nutricionais das essencias florestais, do ciclo de nutri entes, e dos métodos, doses, épocas de aplicação e efeitos na produtividade nas florestas implantadas de Pinus e Eucalyp tus. Assim, ë importante salientar os trabalhos desenvolvidos por: SIMOES e COUTO (1970), SIMOES et alii(1970), SIMOES et alii (1972), CARVALHO (1973), BARROS et alii (1978), BALLONI e SILVA (1978), BRAGA e ROCHA (1979), DeFELLIPO etalii (1979), MORA e BERTOLOTI (1979), MAGALHAES NETO (1980), REZENDE et alii (1980), GONÇALVES e DINIZ (1981), REZENDE et alii (1981), ROCHA (1981), BARROS (1982), REZENDE et alii (1983) e SIMÜES (1983). 


\subsubsection{FERTILIZAÇÃO EM SEGUNDA ROTAÇÄO}

BALLONI e SILVA (1978) consideram importante a adubação de touças em solos de cerrado, recomendando a aplicação em sulcos, entre as linhas pouco antes do corte. Ve rificaram que no caso do Eucalyptus saligna, com 7 anos de i dade, em Sorocaba, a produção volumētrica não apresentou diferenças significativas em função da fertilização das touças. Estes mesmos autores encontraram uma relação direta e altamente significativa entre as fertilizações em cobertura e o desenvolvimento de brotos de Eucalyptus urophilla, com 6 anos de idade, para as condições de Casa Branca, S.P.. 0 fertili zante utilizado em ambos os casos foi de $490 \mathrm{~g} / \mathrm{planta}$ de NPK na fórmula de 6-10-5 em cada época de aplicação, além de uma calagem correspondente a 4 ton/ha, em cada uma das trēs ēpo cas de aplicação consideradas. 0 adubo foi aplicado em cober tura e sem incorporação.

Ainda segundo os mesmos autores, existe uma relação direta e altamente significativa entre as fertiliza ções em cobertura e o desenvolvimento dos brotos. Este ensaio revelou, para as condições em que foi instalado, que é funda mental a aplicação de fertilizantes para um bom desenvolvimento em segunda rotação.

REZENDE et alii (1980) observaram que o desen volvimento de Eucalyptus alba, que recebeu $150 \mathrm{~g} / \mathrm{planta}$ de NPK + Boro e Zinco, na fórmula 10-28-6, logo após o corte, 
foi bem superior aos demais tratamentos (tabela 2 ), sendo a medição realizada um año após o corte. Os autores consideram que é de esperar que tambēm nos tratamentos onde o adubo foi aplicado mais tarde, os resultados sejam positivos.

Tábela 2 - Adubação de cepas de E. alba, na região de Santa Bārbara-MG.

\begin{tabular}{lccc}
\hline \multicolumn{1}{c}{ TRATAMENTO } & $\begin{array}{l}\text { DAP } \\
(\mathrm{cm})\end{array}$ & $\begin{array}{c}\bar{H} \\
(\mathrm{~cm})\end{array}$ & $\begin{array}{l}\text { VOLUME } \\
\left(\mathrm{m}^{3} / \mathrm{ha}\right)\end{array}$ \\
\hline $\begin{array}{l}\text { 1. Testemunha } \\
\text { 2. Adubação apōs retirada do } \\
\text { material (10 dias apōs o }\end{array}$ & 3,22 & 3,97 & 4,376 \\
$\begin{array}{l}\text { corte) } \\
\text { 3. Adubação na desbrota (10 } \\
\text { meses apōs o corte) }\end{array}$ & 3,47 & 4,68 & 6,902 \\
$\begin{array}{l}\text { 4. Adubação 12 meses apōs a } \\
\text { desbrota (ainda não apli- } \\
\text { cado) }\end{array}$ & $3,19^{\circ}$ & 4,33 & 5,436 \\
\hline
\end{tabular}

Fonte: REZENDE et alii (1980).

SIMOES et alii (1981) mencionam que até essa data a maioria das empresas não tinha empregado qualquer tipo de adubação na segunda rotação e aquelas que faziam aduba ção, adotaram uma dose de 100 a 150 g/cepa de NPK, geralmente na förmula 10-28-6.

REZENDE et alii (1981) estudaram o efeito de dịferentes épocas de adubação: 30 dias antes do corte do povoamento, na ocasião do corte (antes do abate das árvores) e 30 dias após o corte, e diferentes doses de adubo apiicado em cada época $(0 \mathrm{~g} ; 50 \mathrm{~g}, 100 \mathrm{~g}, 150 \mathrm{~g}$ e $200 \mathrm{~g}): 0$ adubo foi apl $\underline{i}$ 
cado em cobertura em cîrculo, em torno de cada cepa, e foi u tilizado NPK na förmula 10-28-6 + Boro e Zinco.

os primeiros resultados são relativos a uma medição realizada um ano apōs o corte, quando foram observa dos o nūmero de cepas regeneradas, o diāmetro à altura do pei to $(1,30 \mathrm{~m})$ e a altura total de cada broto. Os autores verificaram que as dosagens afetaram significativamente (a nîvel de $1 \%$ de probabilidade) apenas as alturás e volumes. As épocas de aplicação não exerceram efeito significativo. ConcluÍ ram que:

1. A resposta à adubação deve ser maior no prí meiro ano, visto serem os componentes da fórmula utilizada (NPK) facilmente lixiviados ou imobilizados. Daí a validade desta anālise feita um ano depois da implantação.

2. Até esta idade, os resultados evidenciaram que a adubação de reposição fornece resposta bastante expres siva, em termos de desenvolvimento da brotação, o que pode proporcionar uma menor intensidade de cultivos durante o perî́odo de regeneração.

3. As dosagens de adubo superiores a $200 \mathrm{~g}$ de vem ser testadas para que se obtenha um ponto de máximo desenvolvimento volumētrico.

BAENA et alii (1983), estudando a influência da dose de fertilizante e mētodo de aplicação em segunda ro tação de Eucalyptus saligna, aplicaram os seguintes tratamen 
tos:

10. Testemunha.

20. $200 \mathrm{~g}$ NPK, aplicado a lanço, na entrelinha sem incorporação, antes do corte.

30. $400 \mathrm{~g}$ NPK, aplicado a lanço, na entrelinha sem incorporação, antes do corte:

40. Testemunha com sulco na entrelinha.

50. $200 \mathrm{~g}$ NPK, aplicado em sulco na entrelinha, antes do corte.

69. $400 \mathrm{~g}$ NPK, aplicado em sulco na entrelinha, antes do corte.

70. Testemunha com gradagem na entrelinha.

89. $200 \mathrm{~g}$ NPK, aplicado a lanço na entrelinha e incorporação com grade leve, antes do corte.

9o. $400 \mathrm{~g}$ NPK, aplicado a lanço na entrelinha e incorporado com grade leve, antes do corte.

Concluíram que:

1. Não foram constatadas diferenças significa tivas no nūmero médio de brotos por touça, 6 meses após a aplicação de fertilizantes e gradagem.

2. A altura dos brotos foi influenciada pelas diferentes dosageris de fertilizantes utilizados nos tratamen tos.

3. Os melhores tratamentos foram 06 e 03 , que proporcionaram maior desenvolvimento na altura média dos dois brotos dominantes, evidenciando que essas quantidades 
de fertilizante aplicado por touça contribuem efetivamente para o maior crescimento das brotações.

SIMOES (1983) comenta a respeito da fertiliza ção mineral na segunda rotação e indica que respostas consideráveis podem ser obtidas no crescimento da brotação, após - corte raso do eucalipto. A aplicação do NPK deve ser feita de preferencia imediatamente antes do corte, em sulco na entrelinha de ārvores. Tem mostrado, atravēs da experimentação, respostas significativas tambēm quando aplicado o fertilizan te a lanço sobre a superfície do terreno após a exploração. Acrescenta que devido aos custos continuamente elevados dos fertilizantes, estudos merecem ser feitos para melhor adequa ção da fertilização mineral nos reflorestamentos. Formulações e dosagens econômicas devem ser pesquisadas para diferentes tipos de solo e espécies plantadas. Da mesma maneirá, novas fontes de elementos devem ser consideradas, especialmente de fosfatos naturais, mais baratos, porém de baixa solubilida de, cuja dosagem e forma de aplicação precisam ser ajustadas.

\subsection{Densidade Bäsica da Madeira}

BROWNING (1963) define a densidade básica da madeira como a relação entre sua massa absolutamente seca, expressa em gramas, e seu volume verde, expresso em centĩme tros cübicos. 
BLAIR et ali: (1975); FOELKEL e BARRICHELLO (1975); HARRIS et alii (1976); BRITO e BARRICHELLO (1977, 1979, 1980); BARRICHELLO e BRITO (1978); FERREIRA E KAGEYAMA (1978); JANKOWSKY (1979); JUVILLAR (1979, 1980); BARRICHELLO (1980); FOELKEL et alii (1980); e MAGALHAES (1980), afirmam que a densidade bāsica é um dos fatores mais importantes para a determinação da qualidade de uma madeira para ser uti $\underline{\underline{i}}$ zada com fins tecnológicos.

FOELKEL et alii (1971), VAN DER SLOOTEN (1977) e BARRICHELLO e BRITO (1979) comentam que atravēs da densida de básica, ao trabaihar-se com madeira que é usualmente com prada em volume, é possível se conhecer seu peso seco obtendo-se, com isso, um adequado contróle das operações indus triais.

SILVA (1984) comenta que a determinação da den sidade básica permite a obtenção da estimativa do peso da ma deira por metro cúbico sōlido, metro cübico émpilhado (estēreo) ou permite expressar a produtividade da floresta em ter mos de peso de matēria seca por hectare, o que é sobremane ra importante em termos de transporte, armazenamento e outras operações de controle de matéria-prima. 


\subsection{1, VARIAC,ÄO DA DENSIDADE DA MADEIRA COM AS TAXAS DE CRESCIMENTO}

Hā dados conflitantes sobre a relação entre densidade e taxa de crescimento da ārvore. As opiniões encon tradas na literatura são muito divergentes.

Segundo ERICHSON e LAMBERT (1958), o efeito que as fertilizações tẽm sobre a densidade específica ē mui to variado. Se o tratamento afeta a porção referente à made ra inicial em um anel, elevando-a, a densidade específica di minui. Se eleva a porcentagem de madeira tardia, a densidade específica aumenta. Nos casos em que as maiores taxas de cres cimento produzem uma pequena redução da densidade específica, este efeito resulta insignificante se comparado com o major yolume de madeira que se obtém por meio dos tratamentos de fertilização.

FERREIRA (1968), estudando a variação da den sidade em função do vigor das ārvores, verificou para $E$. saligna, um acréscimo na densidade média da ārvore com o aumen to do DAP.

KLEM (1968), estudando os efeitos da fertilização nas características da qualidade da madeira, observou que a densidade da madeira, apōs fertilização, dependerā do crescimento das ārvores antes do tratamento. Assim, para as ärvores com ritmo de crescimento extremamente baixo, a ferti 
lização provoca um aumentio na densidade, enquanto que naque las de crescimento médio ou räpido, pode-se constatar uma re dução ou nenhuma resposta ao tratamento.

BRASIL e FERREIRA (1971), estudando a variação da densidade básica da madeira de Eucalyptus alba, E. saligna e E. grandis, com cinco anos de idade, na região de MogiGuaçu, S.P., verificaram que a densidade da madeira foi in fluenciada pela taxa de crescimento.

FERREIRA (1973), analisando o comportamento das espécies de eucalipto mais plantadas no Estado de São Pau 10, encontrou uma densidade menos elevada em regiōes mais fér teis e, consequentemente, com maior taxa de crescimento anual. Considerou que uma menor densidade pode ser compensada pela maior produtividade em volume.

Estudos realizados por FERREIRA et alii (1979) com Eucalyptus urophylla, E. saligna e E. grandis em MogiGuaçu, S.P., não encontraram efeito significativo da taxa de crescimento na derisidade básica da madeira.

SouzA et alii (1979), estudando a densidade bā sica da madeira de Eucalyptus microcorys cultivado na região de Dionísio, M.G., concluíram que a densidade nẵo foi altera da pelas taxas de crescimento.

ALBINO (1983); estudando doze espécies de eu- 
calipto, verificou que os locais que apresentaram maior taxa de crescimento proporcionaram menores valores de densidade básica. Os Tocais de solos mais férteis resultaram árvores de maior crescimento em altura e diāmetro, resultando, em contrapartida, uma madeira de densidade básica menor.

\subsubsection{PORTO DE AMOSTRAGEM}

NYLINDER (1965) propōs como padrão internacio nal, usado em silvicultura para a determinação da densidade básica, o DAP (diâmetro à altura do peito, medido poir conven ção a $1,30 \mathrm{~m}$ do solo). Em seus estudos realizados procurou encontrar uma correlação atrávēs de equações matemáticas, pa ra cada espécie e em diferentes condições ambientais, para a densidade média obtida ao DAP com a densidade bäsica média das ārvores.

FERREIRA (1968 e 1970), estudando as variações da densidade de vārias espēcies do gēnero Eucalyptus, concluiu que tanto secções transversais, como amostras obtidas com a Sonda de Pressler,tomadas ao nível do DAP, podem servir como parâmetro quantificador da densidade básica média da ärvore.

BRASIL et alii (1979) e BARRICHELLO et alii (1980), reforçam a afirmativa anterior, concluindo que os re sultados experimentais mosiraram que é possivel determinar a 
densidade bāsica média da ārvore, a partir da densidade obti da em discos amostrados no DAP, através da equação de regres. são 7 inear. 


\section{MATERIAL E MÉTODOS}

\subsection{Material}

O experimento foi instalado no municipio de Lençōis Paulista, S.P., na fazenda Rio Claro, de propriedade 'da Duraflora Silvicultura e Comércio Ltda.

\subsubsection{LOCALIZAÇÄ́}

A fazenda Rio Claro situa-se em cotas altitu dinais de 600 a $750 \mathrm{~m}$. As coordenadas geogräficas do ponto central da propriedade são $22^{\circ} 48^{\prime} \mathrm{S}$ e $48^{\circ} 55^{\prime} \mathrm{W}$, aproximadamente. A vegetação primitiva dominante na região ê. de cerrado.

\subsubsection{ESPËCIE}

A espēcie escolhida para o experimento foi-Eucalyptus saligna Smith, cujas sementes foram provenientes do 
Horto Florestal de Mairinque, SP.

\section{$3,1,3$, SOLO}

0 experimento foi instalado em solo tipo Latos solo Vermeiho-Amarelo, fase arenosa, profundo, bem drenado e de classe textural barro argilo-arenosa, ä́cido e de baixa fertilidade (Comissão de Solos, 1960).

Amostras colhidas no local do experimento em julho de 1985, das parcelas adubadas e não adubadas, foram $\underline{a}$ nalisadas no Instituto Campineiro de Anālise de Solos e Adubo, em Campinas, S.P.:

os resultados analiticos são apresentados na

Tabela. 3 .

Tabela 3 - Resultados analiticos das amostras do solo do local em estudo.

\begin{tabular}{|c|c|c|c|c|c|c|c|c|c|c|c|}
\hline & \multicolumn{5}{|c|}{$\mathrm{pH}$} & \multicolumn{3}{|c|}{ Ions trocāveis } & \multicolumn{2}{|c|}{$\mathrm{meq} / 100 \mathrm{mi}$} & TFSA \\
\hline & $\begin{array}{l}\text { Profundidade } \\
\quad(\mathrm{cm})\end{array}$ & $\mathrm{CaCl}_{2}$ & āgua & $\begin{array}{c}\text { Carbono } \\
(\%)\end{array}$ & $P(p p m)$ & $\mathrm{k}$ & $\mathrm{ca}$ & $\mathrm{Mg}$ & AT & $H$ & CTC \\
\hline$S / A$ & $0-30$ & 4,1 & 4,9 & 0,6 & 1,0 & 0,02 & 0,1 & 0,2 & 0,8 & 1,7 & 2,8 \\
\hline$C / A$ & $0=30$ & 4,0 & 4,8 & 0,7 & $2,0)$ & 0,03 & 0,1 & 0,1 & 1,0 & $2,7^{\circ}$ & 3,3 \\
\hline$S / A$ & $30-70$ & 4,1 & 4.9 & 0,4 & $1,0$. & 0,01 . & 0,1 & 0,1 & 1,0 & 1,7 & 2,9 \\
\hline$C / A$ & $30-70$ & 4,0 & 4,8 & 0,5 & 1,0 & 0,02 & 0,1 & 0,1 & 0,9 & 2,0 & 3,1 \\
\hline$S / A$ & $70-740$. & $4,1^{\circ}$ & 5,0 & 0,2 & 1,0 & 0,01 & 0,1 & 0,1 & 0,8 & 1,6 & 2,6 \\
\hline C/A & $70-140$ & 4,2 & 5,2 & 0,3 & 1,0 & 0,03 & 0,1 & 0,1 & 0,7 & 2,0 & 2,9 \\
\hline
\end{tabular}




\subsubsection{CLIMA}

0 ti.po climático regional pelo sistema de Koep pen è o Cwa, que é um clima mesotérmico de inverno seco, em que a temperatura do mês mais quente ultrapassa os $22^{\circ} \mathrm{C}$ e a do mês mais frio é inferior a $18^{\circ} \mathrm{C}$, sendo as chuvas do mês mais seco inferior a $30 \mathrm{~mm}$. Segundo SETZER (1966), a precipi tação anual média de Lençōis Paulista é prōxima de $1200 \mathrm{~mm}$, predominando no semestre mais quente; os meses mais chuvosos são dezembro, janeiro e fevereiro. A temperatura média anual é de $20,5^{\circ} \mathrm{C}$ aproximadamente; a média do mês mais quente (janeiro) é da ordem de $24^{\circ} \mathrm{C}$, e a do mês mais frio (juiho) è de $17^{\circ} \mathrm{C}$. A ocorrência de geada é de 2 dias por ano, em média.

Durante o periodo de 1974 a 1984, foram cole tados dados climáticos no local do experimento, os quais são apresentados na tabela 4 . 
Tabela 4 - Dados climāticos médios do local do experimento, corresponden tes ao período de 1974 a 1984.

\begin{tabular}{lcccc}
\multicolumn{1}{c}{ Meses } & Māxima & $\begin{array}{c}\text { Temperatura em }{ }^{\circ} \mathrm{C} \text { Minima } \\
\text { Média }\end{array}$ & $\begin{array}{c}\text { Pluviosidade } \\
(\mathrm{mm})\end{array}$ \\
Janeiro & 32,2 & 12,8 & 24,0 & 215 \\
Fevereiro & 32,8 & 12,8 & 23,1 & 195 \\
Março & 31,6 & 10,7 & 22,0 & 140 \\
Abril & 30,0 & 11,0 & 21,0 & 60 \\
Maio & 28,7 & 6,5 & 18,7 & 50 \\
Junho & 24,5 & 5,2 & 18,5 & 56 \\
Julho & 27,0 & 4,1 & 17,0 & 54 \\
Agosto & 29,2 & 5,5 & 17,5 & 28 \\
Setembro & 30,0 & 7,0 & 19,2 & 70 \\
Outubro & 31,2 & 10,8 & 21,0 & 115 \\
Novembro & 31,8 & 10,5 & 22,9 & 120 \\
Dezembro & 31,5 & 12,8 & 23,0 & 155 \\
MEDiA & 30,0 & 9,1 & 20,5 & 1258
\end{tabular}

Com os dados apresentados na tabela 4 , de tem peratura média mensal, anual e precipitação mensal, elaborou -se o balanço hĩdrico do local, seguindo-se o método de TRORN THWAITE e MATHER (1955), apresentado na tabela 5 e figura 1. 
Tabela 5 - Balanço hídrico mensal, segundo THORNTHWAITE e MATHER (1955), para a Fazenda Rio Claro, baseado em dados termo-pluviométri cos do periodo de 1974 a 1984.

$\begin{array}{lcrrrrrrrr}\text { Meses } & \begin{array}{c}P \\ (\mathrm{~mm})\end{array} & \begin{array}{c}\text { ETP } \\ (\mathrm{mm})\end{array} & \begin{array}{l}\text { P-ETP } \\ (\mathrm{mm})\end{array} & \begin{array}{l}\text { Neg. Acum. } \\ (\mathrm{mm})\end{array} & \begin{array}{c}\text { ARM. } \\ (\mathrm{mm})\end{array} & \begin{array}{c}\text { ALT. } \\ (\mathrm{mm})\end{array} & \begin{array}{c}\text { ETR. } \\ (\mathrm{mm})\end{array} & \begin{array}{r}\text { DEF. } \\ (\mathrm{mm})\end{array} & \begin{array}{r}\text { EXC. } \\ (\mathrm{mm})\end{array} \\ \text { Jan. } & 215 & 104 & +111 & & 100 & 0 & 104 & 0 & 111 \\ \text { Fev. } & 195 & 94 & +101 & - & 100 & 0 & 94 & 0 & 101 \\ \text { Mar. } & 140 & 92 & +48 & - & 100 & 0 & 92 & 0 & 48 \\ \text { Abr. } & 60 & 72 & -12 & -12 & 88 & -12 & 72 & 0 & 0 \\ \text { Maio } & 50 & 56 & -6 & -18 & 83 & -5 & 55 & 1 & 0 \\ \text { Junho } & 56 & 46 & +10 & -7 & 93 & +10 & 46 & 0 & 0 \\ \text { Julho } & 54 & 42 & +12 & - & 100 & +8 & 42 & 0 & 5 \\ \text { Ago. } & 28 & 50 & -22 & -22 & 80 & -20 & 48 & 2 & 0 \\ \text { Set. } & 70 & 63+7 & -14 & 87 & +7 & 63 & 0 & 0 \\ \text { Out. } & 115 & 82 & +33 & - & 100 & +7.3 & 82 & 0 & 20 \\ \text { Nov. } & 120 & 92 & +28 & - & 100 & 0 & 92 & 0 & 28 \\ \text { Dez. } & 155 & 101 & +54 & - & 100 & 0 & 101 & 0 & 54\end{array}$

P: Precipitação hĩdrica

ETP: Evapotranspiração potencial

Neg.Acum.: Negativo Acumulado

ARM: Armazenamento de āgua

ALT: Alterações do armazenamento

ETR: Evapotranspiraçã̃o real

DEF: Deficiēncia de água

EXC: Excesso de àgua 


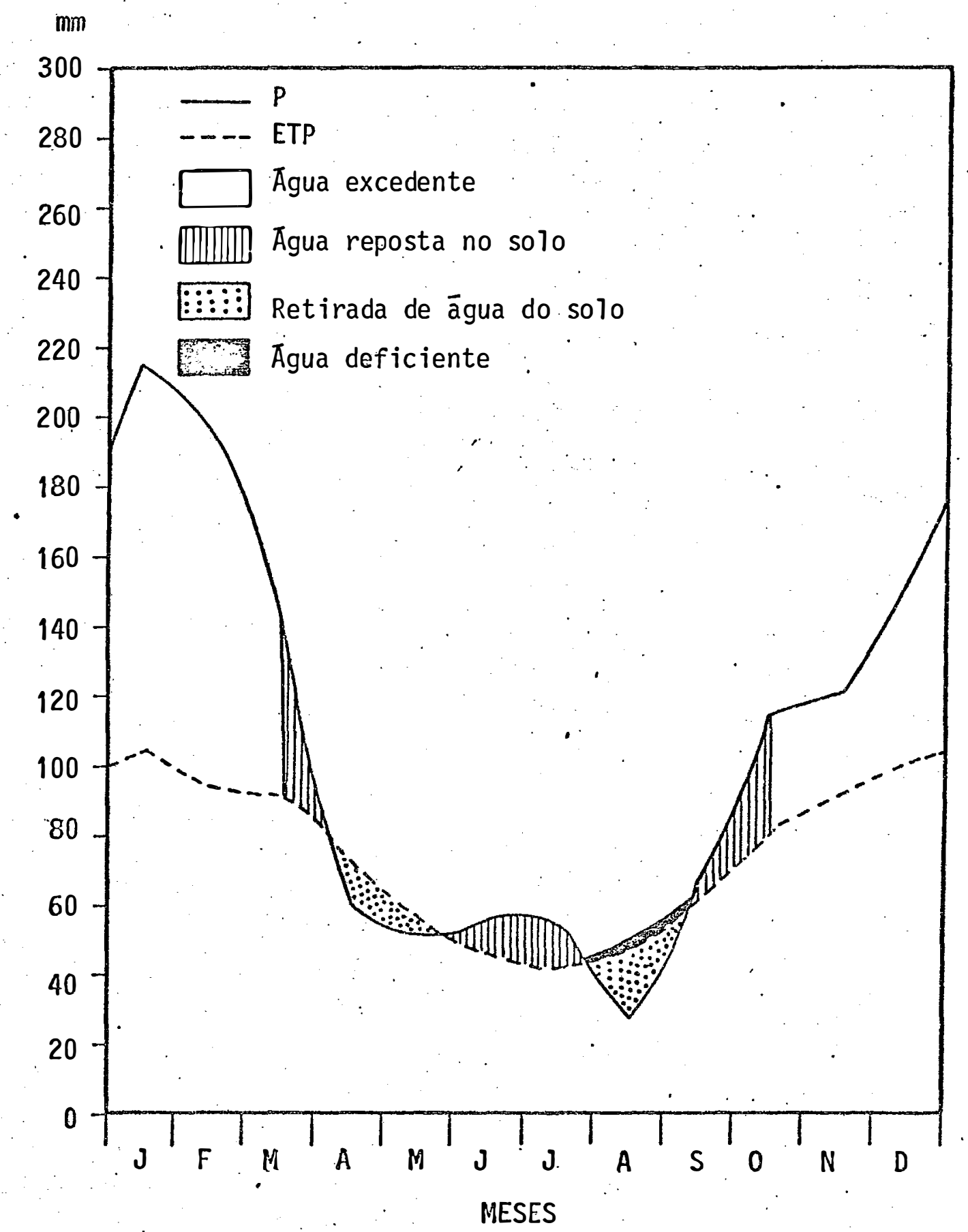

Figura 1 - Balanço hỉdrico do local do experimento, no perĩodo 1974-1984. 


\subsection{MËTODOS}

\subsubsection{DELINEAMENTO EXPER IMENTAL}

Foi adotado o delineamento estatístico fatorial $4 \times 2$, disposto em blocos ao acaso, com 3 repetições. 0s tratamentos aplicados à brotação, foram os seguintes: T1 (sem desbrota e sem adubação; T2 (sem desbrota, com adubação); T3 (1 broto/touça, sem adubação); T4 (1 broto/touça, com adubação); T5 (2 brotos/touça, sem adubação); T6 (2 brotos/touça, com adubação); T7 brotos/touça, sem adubação) e T8 (3 brotos/touça, com adubação).

Cada parcela foi constituída por $121(11 \times 11)$ plantas (touças), das quais somente as $49(7 \times 7)$ centrais fo ram consideradas nas avaliacõos, deixando-se uma bordadura du pra.

\subsection{2, PLANTIO}

0 plantio das mudas no campo foi efetuado em julho de 1972, no espaçamento de $3 \times 1,5 \mathrm{~m}$. 0 primeiro corte raso do povoamento foi feito em jutho de 1978, portanto, aos 6 anos de idade. 0 experimen to: foi instalado sobre as touças remanescentes do primeiro corte, para es tudo do crescimento da brotação em segunda rotação.

Considerando que o espaçamento adotado foi de $3 \times 1,5$ metros, a área ocupada por uma parcela foi de $544,5 \mathrm{~m}^{2}$, resultando em to do o experimento, 24 parcelas, uma ārea total de $13.068 \mathrm{~m}^{2}$. 


\subsubsection{DESBROTA}

Dezesseis meses após o primeiro corte, foi fei ta a desbrota nas parcelas, deixando 1,2 e 3 brotos por tou ça ou sem desbrota, de acordo com o tratamento. A desbrota : foi feita a machado, tomando-se a precaução de deixar os melhores brotos, ou seja, os mais vigorosos e mais bem inseri dos, alēm de observar a uniformidade de distribuição dos mes mos na touça.

\subsubsection{ADUBACÃO}

Foram aplicados $300 \mathrm{~g}$ de NPK da förmula 10-28-6 + B e $\mathrm{Zn}$, à base de $3 \mathrm{~g}$ de sulfato de zinco e $2 \mathrm{~g}$ de bórax por planta.

A dose de adubo correspondente a cada planta foi apl $\underline{i}$ cada em uma faixa de 2,0 $\mathrm{m}$ de largura por $1,5 \mathrm{~m}$ de comprimento, ao longo da linha das plantas, a $30 \mathrm{~cm}$ áa touça e incorporada ao solo por gradagem, imediatamente antes da desbrota.

3.2.4. AVALIAÇÕES DENDROMÉTRICAS DA BROTAC,ÃO DAS TOU ÇAS

As medições de altura total das touças, diāme tro à altura do peito (DAP) e nūmero de falhas foram efetuadas aos 18,29,52,64,76 e 85 meses de idade, ou seja, apōs o corte raso.

Na medição da altura das plantas ūteis das par celas, o aparelho usado foi o Blume-Leiss e, para determina- 
ção do DAP utilizou-se a Suta ou compasso florestal.

Foi feito controle individual por ponto men surāvel, ou seja, a touça ou falha avaliada no primeiro levantamento corresponderamasmesmas dos levantamentos posterio res.

\subsubsection{CÁLCULO DA ALTURA MÉdia E DiẦmETRO MÉDiO}

o cālcuilo da altura média foi obitido através da somatória da altura dos brotos da parcela dividido pelo nú mero total de brotos da parcela.

A determinação do diâmetro médio foi feita $\underline{a}$ través da raiz quadrada da somatória dos diāmetros à altura do peito dos brotos da parcela elevados ao quadrado dividido pelo número total de brotos da parcela.

\subsubsection{CÁLCULLO DA ÁrEA BASAL MÉdia POR hECTARE}

0 valor médio da área basal por parcela foi obtido através da somatória das āreas basais individuais de cada broto da parcelá, através da seguinte fórmula:

$$
A B i=\frac{\pi}{4} D A P^{2}
$$

onde:

$$
\begin{aligned}
& A b i=\text { área basal individual } \\
& D A P=\text { diâmetro à altura do peito }
\end{aligned}
$$


A transformação para ārea basal por hectare foi efetuada conforme a expressão apresentada a seguir:

$$
A B=\sum_{i=1}^{n} A b i \times \frac{10000}{A P}
$$

onde:

$$
\begin{aligned}
& A B=\text { área basal por hectare } \\
& A P=\text { área da parcela }
\end{aligned}
$$

3.2.7. CÁLCULO DO VOLUME CILİNDRICO

O cálculo do volume cilindrico por parcela foi obtido pela somatória dos volumes individuais de cada broto da parcela, através da seguinte fórmula:

$$
V C_{p p}=\Sigma V C_{i}=\Sigma\left(\frac{\pi}{4} D A P^{2} \times H\right)
$$

onde:

$$
\begin{aligned}
V C p P & =\text { volume cilindrico por parcela } \\
V C i & =\text { volume cilindrico individual } \\
\text { DAP } & =\text { diâmetro à altura do peito } \\
H & =\text { altura total }
\end{aligned}
$$

A tránsformação do volume cilindrico por par cela para volume cilindrico por hectare, foi efetuada confor me apresentado a seguir: 


$$
V C=V C p p \times \frac{10000}{A p}
$$

onde:

$$
\begin{aligned}
V C & =\text { volume cilindrico por hectare em } \mathrm{m}^{3} / \mathrm{ha} \\
V C p p & =\text { volume cilindrico por parcela } \\
A p & =\text { área da parcela. }
\end{aligned}
$$

\subsection{8, ANĀLISE ESTATİSTICA DOS DADOS EXPERIMENTAIS}

A sobrevivênciá, a altura total média, o, DAP médio, a ārea basal e o volume cilíndrico, foram. submetidos à anālise de variância e as médias dos tratamentos, comparadas pelo teste de Tukey, segundo GOMES (1.970). Essas anālises foram realizadas para as avaliações feitas aos 18, 29, 52 , 64,76 e 85 meses de idade da brotação.

os dados de número de touças sobreviventes por parcela foram transformados em arcoseno $\sqrt{x+0,5}$.

Considerando que o crescimento do DAP médio, da altura total média e a produção em volume, poderiam ter sofrido a influência do nümero de falhas, os DAP mēdios finais, as alturas médias finais e as produções volumētricas fi nais (volume cilindrico), para cada parcela, foram submetidos a uma anālise de covariância, e as mēdias ajustadas dos tratamentos foram comparadas pelo teste de Tukey, segurido GO MES (1970). 


\subsubsection{AMOStRAGEM PARA A DETERMIMAÇÃO DOS PARÂMIETROS DENDOREETRICOS}

Uma vez efetuada a ūitima medição antes do corte raso final da brotação, as touças üteis de cada parcela foram agrupadás em 5 classes diamétricas (intervalo entre diâmetro mînimo e máximo). Nas touças que continham mais de um broto foi usada a média deles.

De cada parcela do experimento foram marcadas 5 tọças, uma em cada classe diamétrica para efetuar o corte.

As touças selecionadas foram abatidas a 0,10 $m$ do solo. Foram determinados os diãmetros com e sem casca nas secções das extremidades das toras de $2,50 \mathrm{~m}$ de comprimento em que foi desdobrado cada broto de cada touça. 0 dia -metro de cada secção foi a mëdia de duas medições perpendicu lares, com precisão de $0,001 \mathrm{~m}$, através da régua graduada em milimetros. Em seguida, foi empilhada a madeira destas 5 tou ças por parcela, e medido o respectivo volume empilhado.

\subsubsection{CUBICAÇÃO DOS BROTOS}

Os brotos de cada touça foram cubicados por cubagem rigorosa, de modo a formar o volume real de madeira com e sem casca. 0 volume de cada touça era a soma dos volumes de todos os brotos pertencentes àquela touça. Para a cu bicação dos brotos foi utilizada a fórmuia composta de Śma- 
lian.

A fórmula de Smalian pode ser expressa da seguinte maneira:

$$
V=L\left(\frac{A_{0}+A n}{2}+A_{1}+A_{2}+\ldots \ldots+A_{n-1}\right)
$$

onde:

$V$ = volume dos brotos

$L$ = comprimento da tora, neste caso igual a $2,5 \mathrm{~m}$

$A_{1}=$ àrea transversal ná base do broto

$A_{n}=$ ārea transversal no topo do broto

$A_{1}, A_{2} \ldots \ldots A_{n-1}=$ ärea transiversal em cada secção

\subsubsection{CÁLCULO DO FATOR DE FORMA}

0 fator de forma, por tratamento, foi determi nado atravēs da média aritmética dos fatores de forma dos bro tos amostrados em cada tratamento. Eles foram calculados di vidindo-se o volume real pelo volume cilindrico de cada bro to, como se mostra na seguinte expressão:

$$
F \cdot F=\frac{V R}{V C}
$$

onde:

$$
\begin{aligned}
F . F . & =\text { fator de forma } \\
V R & =\text { volume real } \\
V C & =\text { volume cilindrico }
\end{aligned}
$$




\subsubsection{CÁlCCULO DA PORCENTAGEM de CAsCA}

$\therefore$ A estimativa da porcentagem de casca por tra tamento foi obtida através da seguinte expressão:

$$
\% C=\frac{V R C C-V R S C}{V R C C} \times 100
$$

onde:

$$
\begin{aligned}
& \% C=\text { porcentagem de casca } \\
& \text { VRCC = volume real com casca } \\
& \text { VRsC = volume real sem casca }
\end{aligned}
$$

\subsubsection{CÁLCULO RO FATOR DE EMPILHAMENTO \\ O fator de empilhamento por tratamento foi determinado atravēs da seguinte relação:}

$$
F e=\frac{V E}{V R}
$$

onde:

$$
\begin{aligned}
F e= & \text { fator de empilhamento } \\
V E= & \text { volume empilhado (o qual foi obtido do empilhamen } \\
& \text { to das toras resultantes do seccionamento dos bro- } \\
& \text { tos das } 5 \text { touças amostradas por tratamento) } \\
V R= & \text { volume real (o qual foi obtido da cubagem rigorosa } \\
& \text { dos brotos das } 5 \text { touças por tratamento). }
\end{aligned}
$$




\subsubsection{DENSIDADE BÄSICA}

A coleta de amostras de madeira para densida de foi feita das 5 touças selecionadas em cada classe diamé trica. Foram retirados discos de $3 \mathrm{~cm}$ de espessura no DAP de todos os brotos de cada touça.

Para a determinação da densidade bāsica da madeira, os discos foram seccionados e retiradas amostras pa ra os ensaios. Os corpos de prova foram mantidos em āgua sob vácuo intermitente, atē atingirem a completa saturação. A se guir, fọi empregado o método da balança hidrostática (Norma ABCP M 14/70), que consiste em se determinar o peso imerso do corpo de prova, seu peso úmido e absolutamente seco.

o cálculo da densidade básica é feito atravēs da seguinte expressão:

$$
\mathrm{db}=\frac{\mathrm{PS}}{\mathrm{PU}-\mathrm{PI}}
$$

onde:

$$
\begin{aligned}
& \mathrm{db}=\text { densidade básica em } \mathrm{g} / \mathrm{cm}^{3} \\
& \mathrm{PS}=\text { peso absolutamente seco da amostra } \\
& \mathrm{PU}=\text { peso úmido da amostra em } \mathrm{g} / \mathrm{cm}^{3} \\
& \mathrm{PI}=\text { peso imerso da amostra em } \mathrm{g} / \mathrm{cm}^{3}
\end{aligned}
$$

A densidade média de cada haste foi determinada, a partir da densidade obtida dos discos retirados no DAP, utilizando a equação de SOUZA e BARRICHELLO (1985), a seguir: 


$$
Y^{*}=0,147422+0,714161 x
$$

onde:

$$
\begin{aligned}
& Y=\text { deñsidade mēdia da ärvore } \\
& x=\text { densidade no DAP }
\end{aligned}
$$

cujo coeficiente de correlação è $R=0,806206$.

\subsubsection{CORTE FINAL DO EXPERIMENTO}

No corte raso do experimento foi tomado o cuidado de não misturar madeira de parcelas e blocos diferen tes. Para isto, foi identificada cada parcela em cada bloco. Após a derrubada, os brotos foram seccionados em toras de $2,50 \mathrm{~m}$ de comprimento, a partir da base até um diâmetro mínimo de $3 \mathrm{~cm}$ com casca. As toras de cada parcela foram empilhadas e seu volume medido. A esta madeira empilha da se the somou a madeira empilhada das 5 touças amostradas anteriormente. 0 resultado é o volume de madeira empilhada por parcela, expresso em estēreo $\left(\simeq \mathrm{m}^{3}\right)$.

os dados da densidade básica, de volume de ma deira cortada e da produção em peso de madeira, estimado a partir da ūltima avaliação aos. 85 meses de idade, foram submetidos à anālise de variāncia. 


\section{RESULTADOS E DISCUSSÃO}

\subsection{ALTURA tOTAL DOS BROTOS}

A Tabela 6 apresenta os contrastes entre as mēdias da variävel altura dos brotos de toucas por tratamento, nas diferentes épocas de medicão $(18,29,52,64,76$ e 85 meses de idade). 
Tabela 6 - Comparação entre médias de altura $(m)$ do brotos das touças de Eucalyptus saligna Smith, nas diferentes épocas de medição.

\section{Medições}

Tratamentos

\begin{tabular}{llllll}
\hline & & Meses de idade & $\therefore$ \\
\hline 18 & 29 & 52 & 64 & 76 & 85 \\
\hline
\end{tabular}

4-1 broto C/A 6,22 a 9,51 a 14,43 a 14,97 a 16,01 a $16,46 a$

3-1 Broto S/A 5,41 a 8,01 bc 12,42 ab $\uparrow 3,35$ ab 14,28 ab $14,84 a b$

8-3 Brotos C/A 6,24 a 8,36 ab 12,42 ab 13,35 ab 14,13 ab $14,19 a b$

6-2 Brotos C/A 5,98 a 8,67 ab 12,46 ab 13,26 ab $\{4,03$ ab $14,09 a b$

5-2 Brotos S/A 5,48 a 8,00 bc 11,98 abc 12,60 ab 13,39 ab 13,68 b

2-Sem desbrota

C/A $\quad 5,78$ a 7,26 bc 10,99 bc $\cdot 11,58$ bc 12,34 bc $12,56 b c$

7-3 Brotos S/A 5,46 à 7,24 bc 10,98 bc 11,37 bc 12,15 bc 12,27bc

1-Sem desbrota

S/A $\quad 5,33$ a. $\quad 6,76$ c $\quad 9,51$ c $\quad 10,07$ c ${ }_{\leftrightarrow} 10,67$ c $\quad 10,87$ c

\begin{tabular}{lrrrrrrr} 
Média & 5,74 & 7,98 & 11,87 & $\therefore$ & 12,57 & 13,38 & 13,62 \\
C.V.(\%) & 6,27 & 6,42 & 7,58 & & 6,94 & 6,90 & 7,02 \\
\hline
\end{tabular}

1 Variāveis seguidas da mesma letra não diferem estatisticamente ao nīvel de $5 \%$ de probabilidade.

S/A: sem adubo; C/A: com adubo. 
A Tabela 7 apresentia a comparacão de médias por tratamento, resultantes da análise em fatorial da variável altura, aos 85 meses de idade.

Tabela 7 - Comparação entre as médias de altura total (m) para os trata mentos.

Fertilização $\quad$ Altura mēdia $(m) \quad$ Altura $(\%)$

\begin{tabular}{lll}
\hline $\begin{array}{c}\text { g/touça } \\
300 \mathrm{~g} / \text { touça }\end{array}$ & $12,91 \mathrm{~b}$ & 100,00 \\
\hline Condução da touça & $14,33 \mathrm{a}$ & 111,00 \\
\hline Sem desbrota & Altura média (m) & Altura (\%) \\
1 broto/touça & $11,72 \mathrm{c}$ & 100,00 \\
2 brotos/touça & $15,65 \mathrm{a}$ & 133,53 \\
3 brotos/touça & $13,89 \mathrm{~b}$ & 118,52 \\
\hline
\end{tabular}

A Figura 2 representa a evolucão do crescimen to médio, em altura, dos brotos das toucas. 


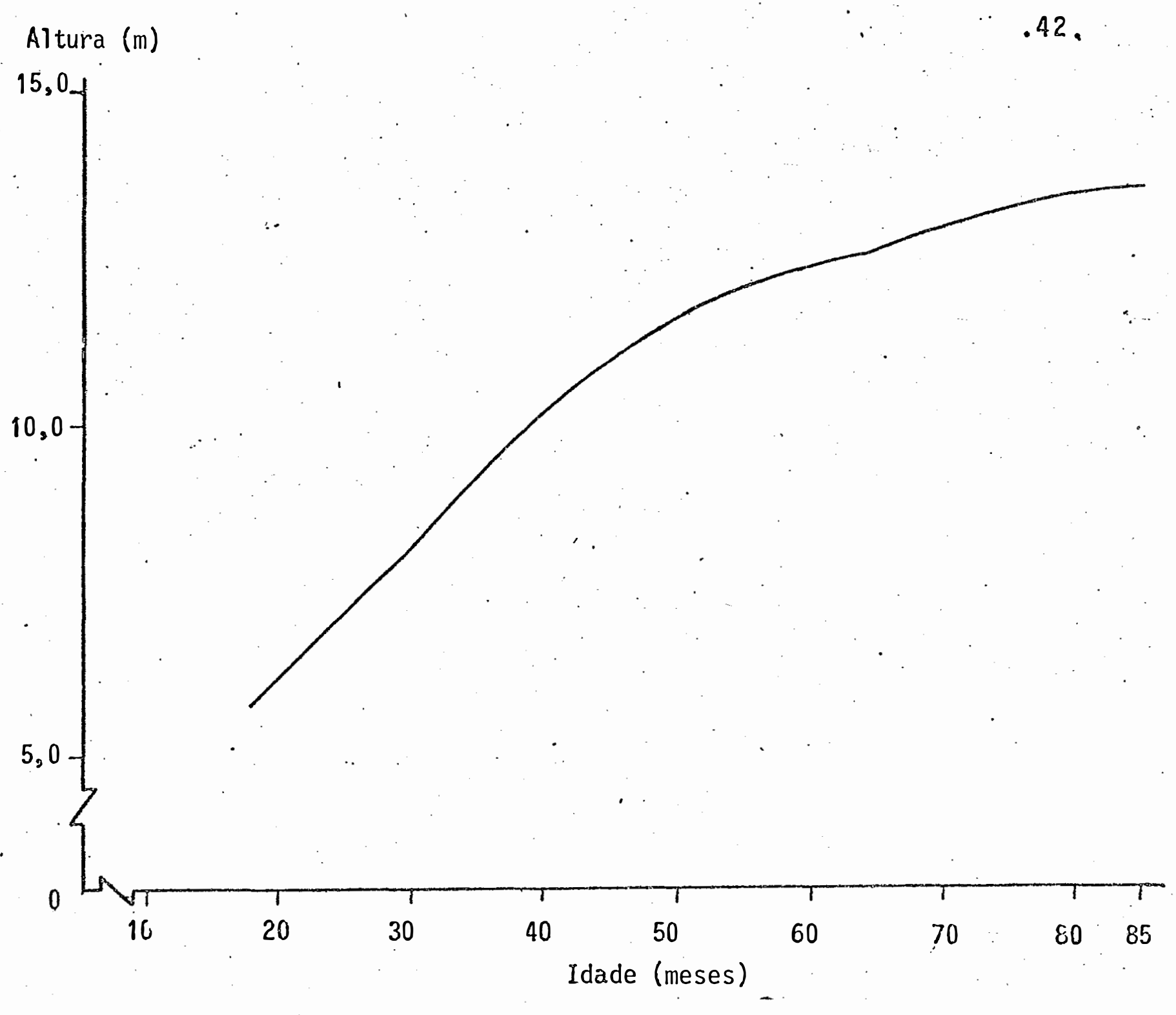

Figura 2 - Curva de crescimento em altura média (m) dos brotos em função da idade.

A Figura 3 representa o crescimento médio em a tura total dos brotos, em função do nümero de brotos por touca. 


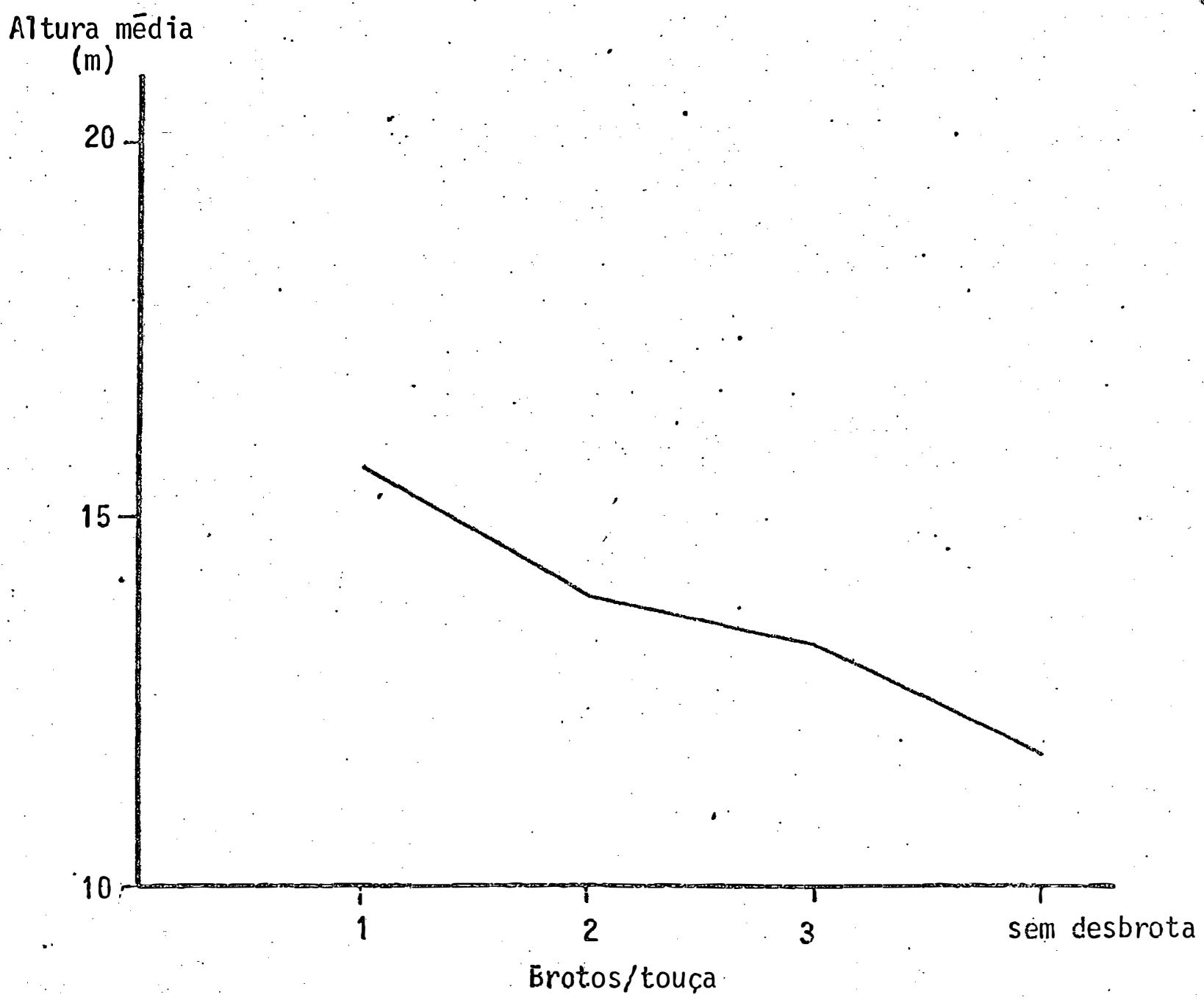

Figura 3 - Altura média (m) dos brotos em função do número de brotos por touça, aos 85 meses de idade.

Observa-se pela Tabela 6 , que aos 18 meses, a altura não diferiu entre os tratamentos, iniciando sō aos 29 meses.

Quando se comparam as médias de tratamentosadubados e não adubados, com um mesmo nūmero de brotos, não se encontrou diferenca significativa entre eles. Entretanto, 
nos contrastes de médias de tratamentos adubados e não aduba dos, com diferentes número de brotos, o teste de Tukey revela diferenças significativas ao hĩvel de $5 \%$.

0 número de brotos influenciou o crescimento em altura e a tendência observada consistiu em que o menor nūmero de brotos, resultou em maior crescimento em alitura, com excecão do tratamento 8 ( 3 brotos com adubacãa), o qual ocupou o 30 lugar em crescimento, a partir da tercejra medicão.

0 tratamento 4 foi o melhor tratamento dando - maior crescimento em altura mostrando diferencas significa tivas nos contrastes dos tratamentos $5,2,7$ e 1.

Quando comparamos o tratamento 3 (1 broto sem adubo) com o tratamentio 1 (sem desbrota e sem adubo) se pode observar que houve diferenca, significativa. No entanto, quando comparamos o tratamento 3 com o tratamento 2 (sem desbrota com adubo)não existiu diferenca significativa entre eies.

No geral a adubação fornece respostas positivas para o crescimento em altura, quando se comparam tratamentos com menor número de brotos com áqueles que possum maior núnero de brotos. Isto è devido a que quanto maior o número de inàivíduos por $\bar{a}-$ rea, maior serā a competição por āgua, nutriente e espaço vitaís prodú zindo com isto um efeito negativo no crescimento em altura. o coeficiente de variação é baixo em todas as medições. 
A Figura 2 mostra que o crescimento dos brotos das toucas, em altura, aos 7 anos ainda era ativo, embora o incremento periódico tenha-se reduzido a partir dos 52 meses de idade.

Observa-se na Tabela 7 que quando se comparam os contrastes das médias do crescimento em altura dos brotos, dos tratamentos adubados e não adubados, se encontrou diferenca significativa ao nivel de $5 \%$ de probabilidade, existin do em média uma superioridadé de $11 \%$ dos tratamentos adubados.

- Na comparacão entre os contrastes de mëdias dos tratamentos (sem desbrota, 1,2 e 3 brotos por touca) se verificou diferenças significativas entre o tratamento com um broto e os demais tratamentos, com uma superioridade em rela ç̃̃o ao tratamento sem desbrota de $33,53 \%$, sendo portanto, 0 melhor tratamento.

o tratamento 2 brotos por touça, também foi superior ao tratamento sem desbrota.

A Figura 3 mostra que o crescimento em aitura é beneficiado pela reducão do nūmero de brotos por touça. Verifica-se, de tudo isso que o tratamento que apresentou maior altura foi 1 broto por touca com adubacão. 0 stratamentos 2 e 3 brotos por touca tiveram comportamentos similares entre si quanto à altura.

Não houve interação entre a adubacão e o nūme ro de brotos por touça. 


\subsection{DIÂMETRO À ALTURA DO PEITO (DAP)}

A Tabela 8 apresenta a compração entre médias da variāvel DAP médio dos brotos de touças de Eucalypius sa'igna Smith. nas diferentes épocas de medição $(29,52,64,76$ e 85 meses após o primeiro corte raso do povoamento).

Tabela 8 - Comparação entre diāmetros médios (DAP); por tratanento, dos brotos das touças $(\mathrm{cm})$, de Eucalyptus saligna Smith, nas diferentes épocas de medição.

Medições

Tratamento

\begin{tabular}{lccccc}
\hline \multicolumn{5}{c}{ Meses de idade } \\
\hline \multicolumn{7}{c}{59} & 52 & 64 & 76 & 85 \\
\hline $7,69 \mathrm{a}$ & $10,25 \mathrm{a}$ & $10,57 \mathrm{a}$ & $10,95 \mathrm{a}$ & $11,77 \mathrm{a}$ \\
$6,47 \mathrm{~b}$ & $8,98 \mathrm{ab}$ & $9,57 \mathrm{ab}$ & $9,68 \mathrm{ab}$ & $10,36 \mathrm{ab}$ \\
$6,09 \mathrm{~b}$ & $8,01 \mathrm{bc}$ & $8,33 \mathrm{bc}$ & $8,38 \mathrm{bc}$ & $8,97 \mathrm{bc}$ \\
$5,85 \mathrm{bc}$ & $7,83 \mathrm{bc}$ & $8,09 \mathrm{bc}$ & $8,16 \mathrm{bc}$ & $9,05 \mathrm{bc}$ \\
$5,67 \mathrm{bcd}$ & $7,85 \mathrm{bc}$ & $8,21 \mathrm{bc}$ & $8,16 \mathrm{bc}$ & $8,75 \mathrm{bc}$ \\
$5,02 \mathrm{cde}$ & $6,74 \mathrm{~cd}$ & $7,00 \mathrm{~cd}$ & $7,15 \mathrm{~cd}$ & $7,70 \mathrm{~cd}$ \\
A & $4,77 \mathrm{de}$ & $6,46 \mathrm{~d}$ & $6,78 \mathrm{~cd}$ & $6,83 \mathrm{~cd}$ & $7,26 \mathrm{~cd}$ \\
A,58 e & $5,71 \mathrm{~d}$ & $6,00 \mathrm{~d}$ & $5,93 \mathrm{~d}$ & $6,41 \mathrm{~d}$ \\
\hline & & & & & \\
\hline 5,77 & 7,73 & 8,07 & 8,16 & 8,78 \\
6,28 & 6,11 & 7,11 & 7,94 & 7,38 \\
\hline
\end{tabular}


A Tabela 9 apresenta a compração de média por tratamento, resultante da anālise. em fatorial da variāvel DAP, aos 85 meses de idade.

Tabelạ 9 - Comparação entre as mëdias do DAP (cm) para os tratamentọ.
Fertilização
Diâmetro médio $(\mathrm{cm})$
Diāmetro (\%)

\begin{tabular}{|c|c|c|}
\hline $0 \mathrm{~g} /$ touça & $8,38 \mathrm{~b}$ & $\because 100,00$ \\
\hline $300 \mathrm{~g} /$ touca & 9,19 a & 109,67 \\
\hline Condução da touça & Diāmetro médio $(\mathrm{cm})$ & Diânietro $(\%)$ \\
\hline Sem desbrota & $6,83 \mathrm{c}$ & 100,00 \\
\hline i broto/touca & $19,07 \quad a$ & 162,08 \\
\hline 2 brotos/touca & $9 ; 01 \mathrm{~b}$ & 131,92 \\
\hline 3 brotos/touca & $8,83 . b$ & 129,28 \\
\hline
\end{tabular}

A Figura 4 mostra a dinâmica do crescimentodo diāmetro mēdio da brotação. 


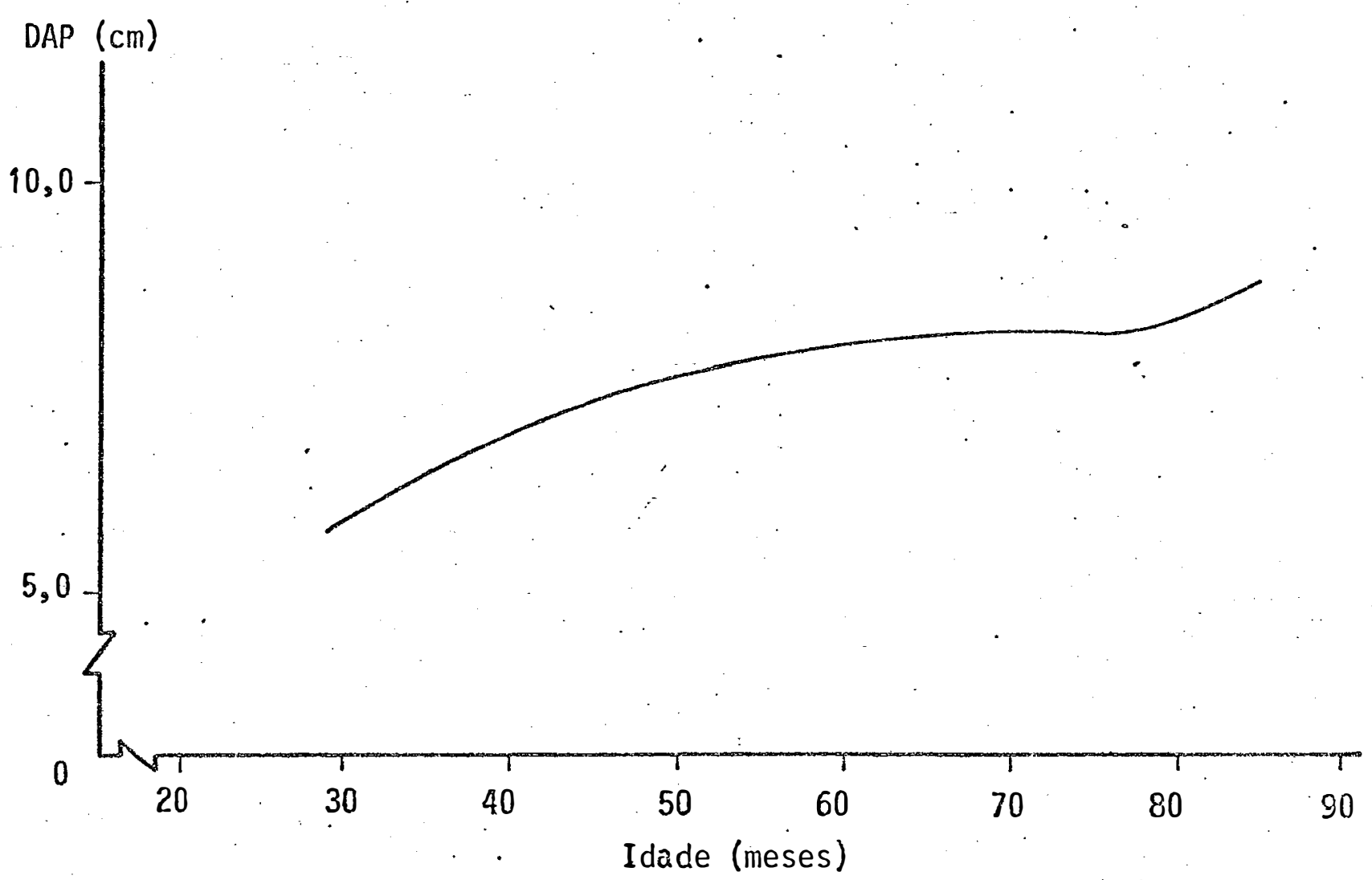

Figura 4 - Curva de crescimento do diâmetro (DAP) em $\mathrm{cm}$, dos brotos em função da idade.

A figura 5 representa o crescimento em diàmetro dos brotos, em funcão do número de brotos por touca, aos 85 meses de idade. 


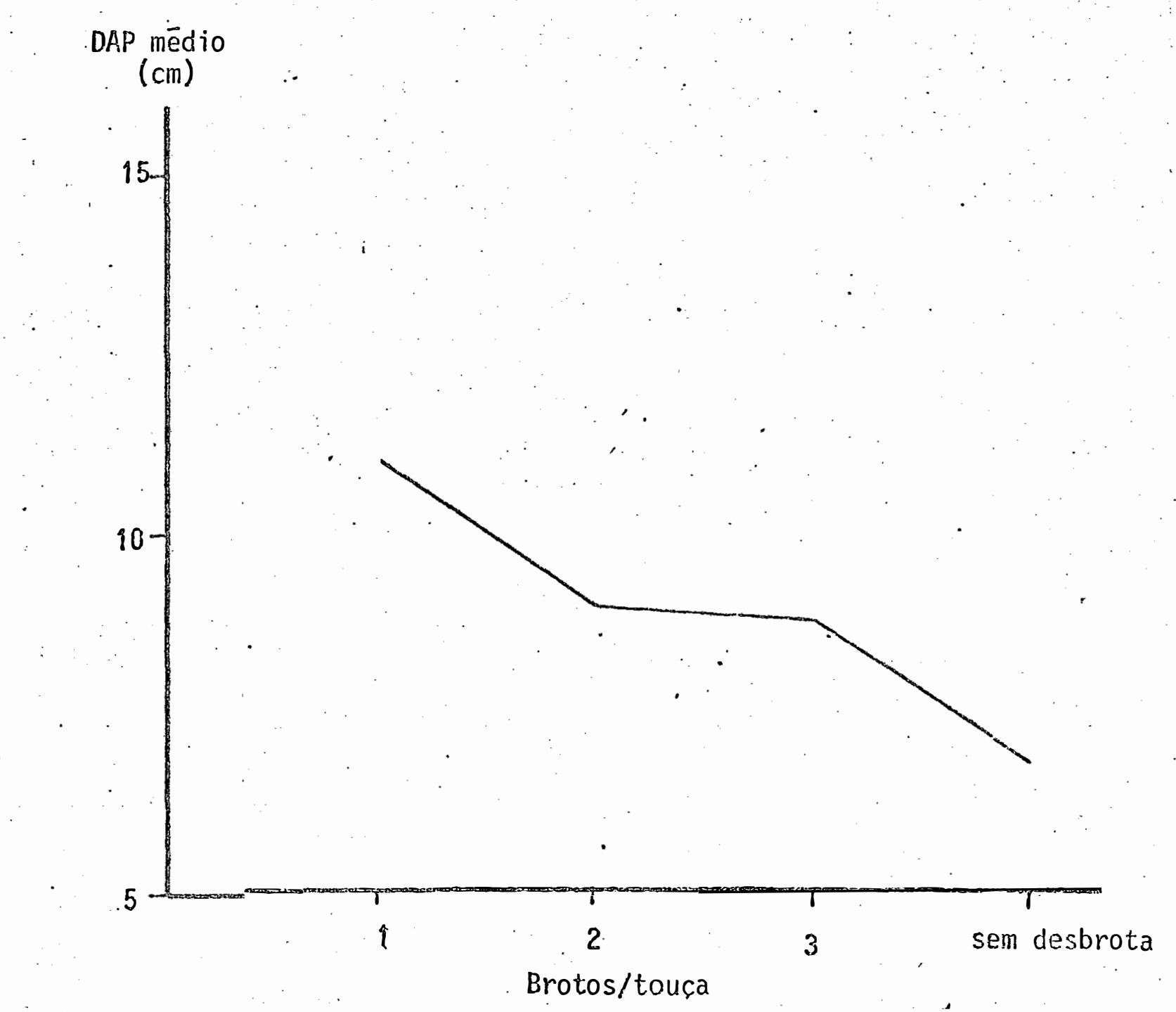

Figura 5 - DAP médio $(\mathrm{cm})$ dos brotos em função do nūmero de brotos por touça.

As comparacões entre mēdias dos tratamentos nas diferentes épocas de medicão, mostraram que o tratamento nümero 4 que consistiu em um broto mais adubação, foi o que apresentou os mais altos valores em diāmetro em todas as ēpocas de avaliação. Quando comparado com o tratamento 3, que 
consistiu em um broto sem adubacão, este apresentou valores estatisticamente não significativos a partir da segunda avaliação (52 meses apōs o corte). Embora os resultados estatîs. ticos não mostrem diferenças entre eles, mas tomando em conta a resposta do tratamento 4, maior do que o tratamento 3 na primeira avaliação e os valores maiores do tratamento 4, em todas as avaíiaços, nōs podemos deduzir que.existe uma vantágem da adubação sobre o crescimento em diāmetro.

Verifica-se que este fáto se confirma na primeira avaliacão, e que dita vantagem continua presente em to das as avaliacões subseqüentes. Os resultados obtidos concor dam com os encontrados por ANDRADE (1961); COUTO (1973); PAI VA et alii (1983), em relação a que maiores diãmetros foram obtidos quando se trabalhou com um broto, alēm do efeito positivo da adubação nas etapas iniciais neste sistema de mane jo, aspecto mostrado no presente trabaiho.

Comparando os demais tratamentos pode-se ob. servar que o diámetro é mais afetado à medida que se aumenta - nümero de brotos e nestas situações e adubação não tem e. feito significativo nesta variāvel estudada.

Por outro lado Jorgensen (1967), citado por COUTo (1973), encontrou que o crescimento em diāmetro é funcão direta da ārea em disposicão de cada planta. Isto vem a confirmar a superioridade em diāmetro dos tratamentos 4 e...3 no presente ensaio, que possuem menor nümero de brotos por $u-$ nidade de ärea. 
0 coeficiente de variação para DAP também $\overline{\mathrm{e}}$ baixo.

Pela Figura 4, observa-se que a tendēncia geral do crescimento em diâmetro era de estagnação a partir da terceira medicão. Porēm, revelou uma reação positiva no ritmo de crescimento dos 76 para 85 meses. Verificando-se a Tabela 7 observa-se que essa reacão ocorreu em todos os tratamentos.

Isto possivelménte seja devido a que a quanti dade de chuva nesse último período de crescimento foi maior que o do período anterior. A precipitacão de novembro de 1983 a. outubro 1984 foi de $1.036 \mathrm{~mm}$ e a chuva caída durante o ūttimo periodo de crescimento (novembro 1984 a juiho de 1985) foi de $1.145,9 \mathrm{~mm}$. Ou seja, em menor período de tempo (9 meses) ocorreu maior precipitacão que durante o ano anterior.

Pode-se observar na Tabela que existiu dife renca significativa a $5 \%$ entre as médias de DAP dos tratamen tos adubados e não adubados, sendo esta superioridade da ordem de $9,67 \%$.

Nos contrastes do DAP em funcão do número de brotos existiram diferencas significativas. 0 tratamento. 1 broto por touca, diferiu estatisticamente dos tratamentos res tantes, mostrando uma superioridade de $62,08 \%$ em relafão ao tratamento sem desbrota.

os tratamentos 2 e 3 brotos por touça não di. feriram estatisticamente entre si, mas foram superiores ao 
tratamento sem desbrota.

A Figura 5 mostrou a mesma tendência da Figura 3 , ou seja que o maior diāmetro foi obtido quando a touca foi conduzida com 1 só broto.

A interação adubação $x$ nūmero de brotos. não foi significativa.

\section{3. ÁREA BASAL}

A Tabela 10 apresenta a comparacão entre médias da variável área basal dos brotos das toucas de Eucalyp tus saligna Smith, nas diferentes ëpocas de medicão (29, 52, 64, 76 e 85 meses após o corte). 


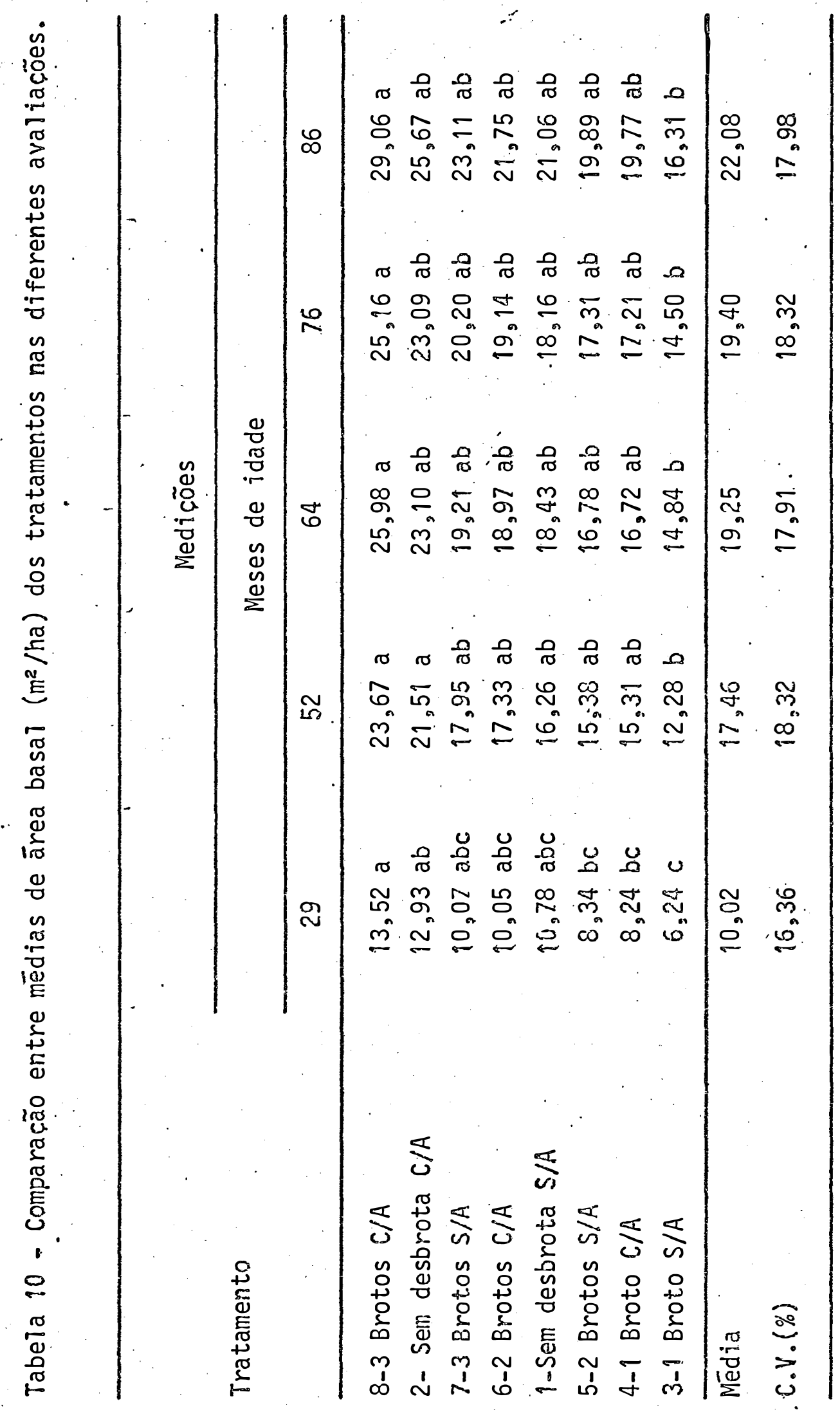


A Tabela 11 apresenta a comparação de mēdias da variāvel ārea basal, analisada como fatorial, aos 85 meses de idade.

Tabela 11 - Comparação entre as mēdias de ārea basal $\left(\mathrm{m}^{2} / \mathrm{ha}\right)$, dos trata mentos.

\begin{tabular}{lcc}
\hline Fertilização & Area basal (m²/ha) & Area basal (\%) \\
\hline $0 \mathrm{~g} /$ touça & $20,09 \mathrm{~b}$ & 100,00 \\
$300 \mathrm{~g} /$ touça & $24,06 \mathrm{a}$ & 119,76 \\
\hline Condução & Area basal (m²/ha) & Area basal (\%) \\
\hline Sem desbrota & $23,36 \mathrm{ab}$ & 129,56 \\
1 broto/touça & $18,03 \mathrm{~b}$ & 100,00 \\
2 brotos/touça & $20,82 \mathrm{ab}$ & 115,47 \\
3 brotos/touça & $26,08 \mathrm{a}$ & 144,65 \\
\hline
\end{tabular}

A Figura 6 representa o comportamento da ārea basal em função da idade. 


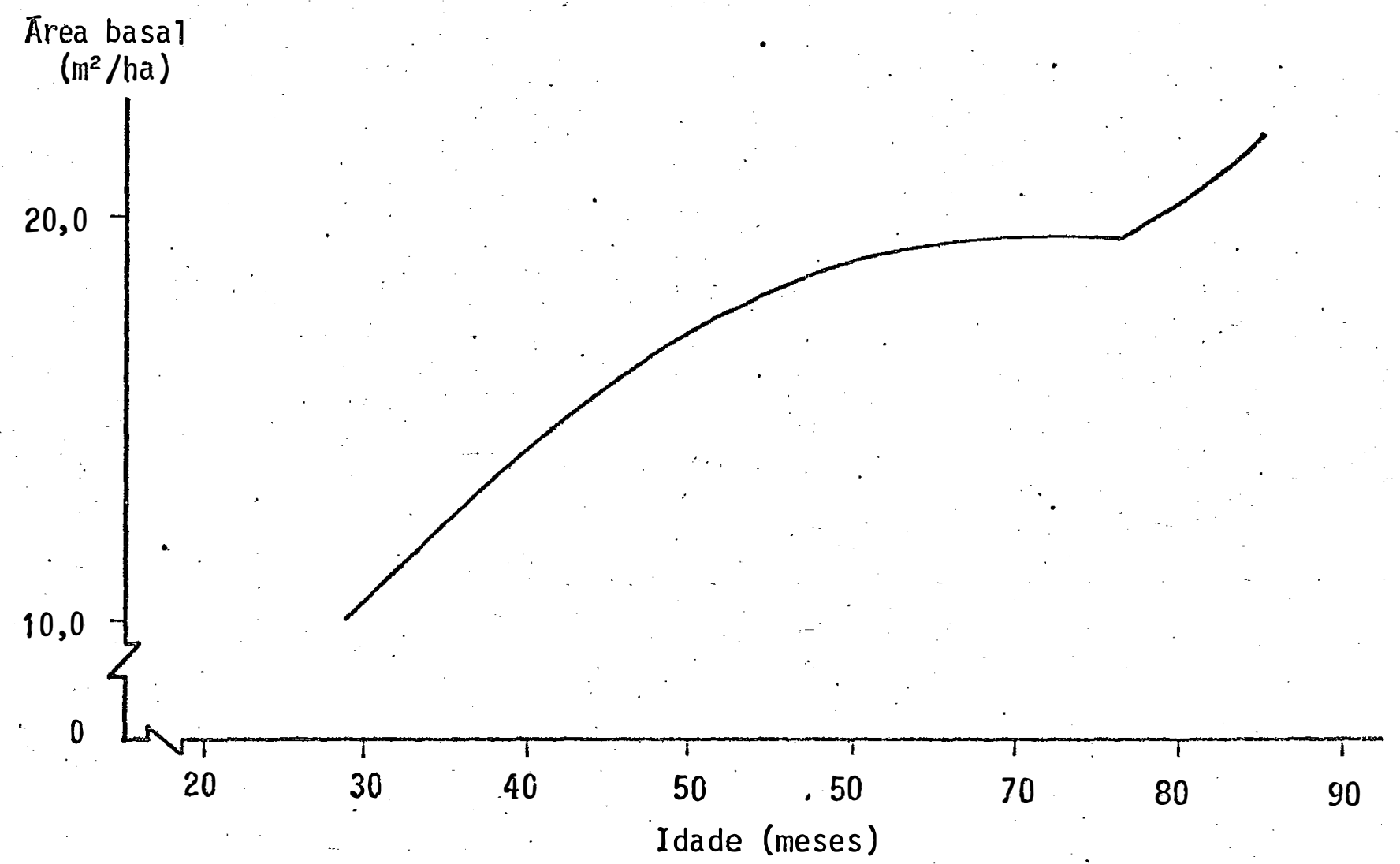

Figura 6 - Curva de crescimento da área basal dos brotos, em função da idade.

A Figura 7 representa o crescimento médio da ārea basal em funcão do nümero de brotos por touça, aos 85 meses de idade. 


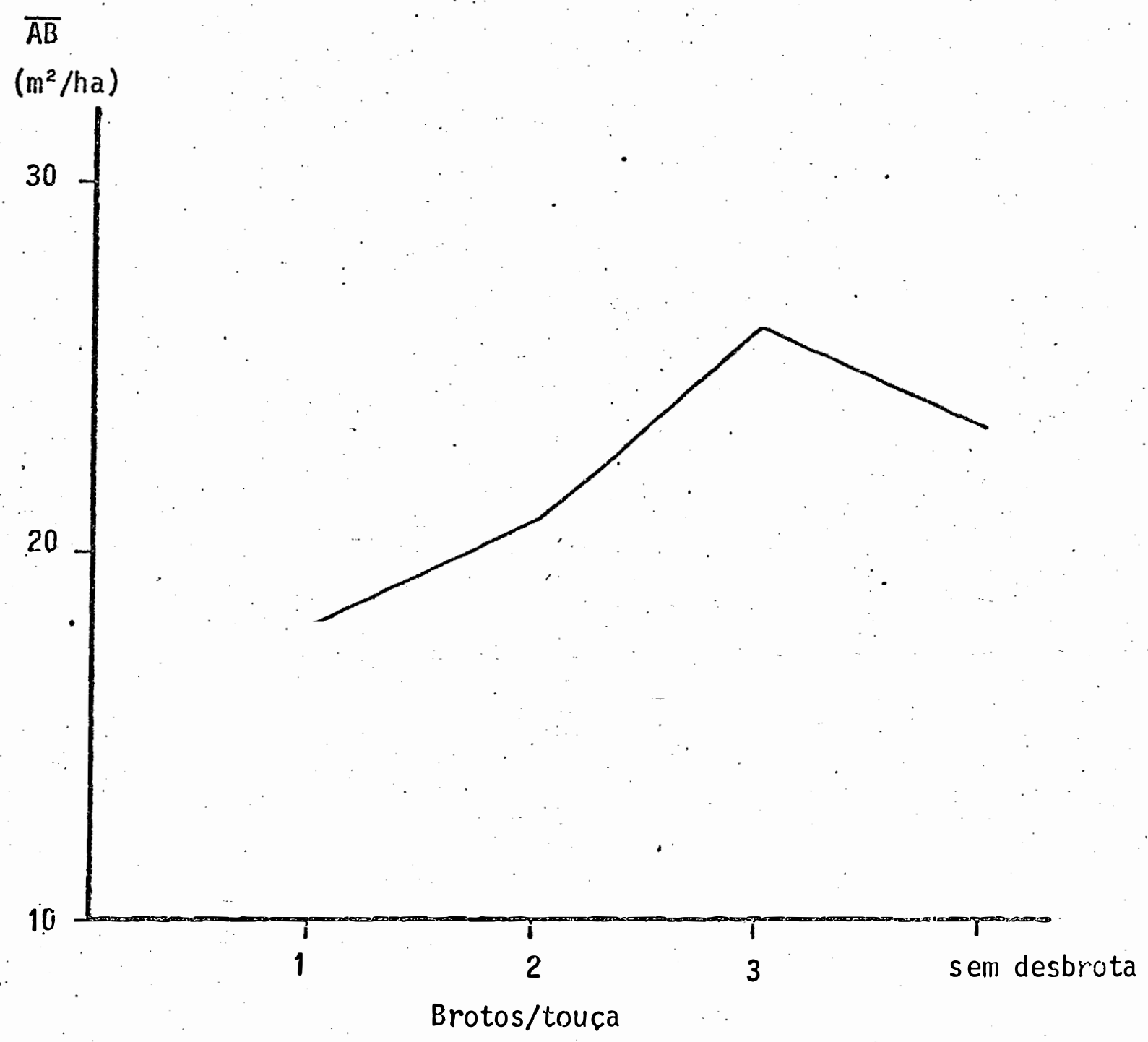

Figura 7 - Area basal dos brotos em unção do nümero de brotos por touça.

As comparacões entre médias jos tratamentos nas diferentes épocas de avaliação, mostram a superioridade do tratamento 8 ( 3 brotos com adubacão), seguido pelos tratamentos 2 (sem desbrota com adubacão), 7 ( 3 brotos sem adubo), 6 ( 2 brotos com adubacão), 1 (sem desbrota sem adubo), 5 (2 brotos sem adubo) e 4 ( 1 broto com adubo), os quais quando com 
parados com o tratamento 8 ou entre eles mesmos, não apresen tam diferencas significativas. A ünica diferença encontrada nos contrastés de médias, foi entre o tratamento 8 e o trata mento 3 ( 1 broto sem adubo).

A área basal foi maior naqueles tratamentos com o maior núméro de brotos ( 3 brotos e sem desbrota), inde pendente da adubação. Mesmo que as comparações das médias dos tratamentos indiquem a não existência de significância entre eles, os tratamentos que receberam adubação sempre estão me- Thor colocados que os respectivos tratamentos não adubados.

0 incremento em diâmetro influiu notavelmente na área basal, a qual foi calculada com base na somatória dás āreas basais dos diferentes brotos presentes em cada touca.

Se compararmos as āreas basais produzidas nos tratamentos adubados e não adubados obteremos:

\begin{tabular}{llll}
\hline Tratamentos & Areas basais $\left(\mathrm{m}^{2} / \mathrm{ha}\right)$ & Diferenca $\left(\mathrm{m}^{2} / \mathrm{ha}\right)$ \\
\hline $8-7$ & $29,06-23,11$ & $=$ & 5,95 \\
$2-1$ & $25,07-21,06$ & 4,61 \\
$6-5$ & $21,75-19,86$ & $=$ & 1,88 \\
$4-3$ & $19,77-16,31$ & 3,46 \\
\hline
\end{tabular}

ou seja, no caso dos tratamentos 8 e 7 a dife rença em ārea basal, produzida pela adubação, foi de $5,95 \mathrm{~m}^{2} / \mathrm{ha}$, 
o que significa, considerando a altura média do teste $(13.62 \mathrm{~m})$, uma diferença de $81,04 \mathrm{~m}^{3}$ no volume cilindrico; $67,79 \cdot \mathrm{m}^{3}$ para os tratamentos 2 e $1 ; 47,13 \mathrm{~m}^{3}$ para o 4 e 3 , e $25,61 \mathrm{~m}^{3}$ para os. tratamentos 6 e 5 .

o coeficiente de variacão subiu sensivelmentè, mas ainda se mantēm em nīveis médios.

A Figura 6 mostra a mesma tendēncia dá Figu ra. 4 por ser conseqüência do crescimento em diâmetro.

Pode-se observar na Tabela 11 que houve diferença significativa entre as médias de crescimento em área basal dos brotos das toucas dos tratamentos adubados e não a dubados, sendo os tratamentos adubados $19,76 \%$ maior que os tratamentos sem adubação.

A comparação entre às médias dos tratamentos; sem desbrota, 1 e 2 brotos por touça, não mostraram diferencas significativas.

0 tratamento 3 brotos por touca diferiu sign $\underline{i}$ ficativamente só do tratamento 1 broto por touça mostrando uma superioridade da ordem de 44,65\%.

Na Figura 7 se observa que a ārea basal aumen tou com o número de brotos até o tratamento de 3 brotos por touça, diminuirido depois, no tratamento sem desbrota, provaveimente, pela maior competicão entre um nümero excessivamente grande de brotos por touca. 


\subsection{VOLUME CILINDRICO}

Os dados apresentados na Tabela 12, referem- se à comparação entre médias da variàvel volume cilîndrico dos brotos de toucas de Eucalyptus saligna Smith, nas diferentes ēpocas de medição $(29,52,64,76$ e 85 meses de idade).

Tabela 12 - Comparação entre médias de volume cilîndrico $\left(\mathrm{m}^{3} / \mathrm{ha}\right)$ de Eucalyptus saligna Smith nas diferentes ëpocas de avaliação.

Medições

Tratamentos

Meses de idade

\begin{tabular}{l|llll}
\hline 29 & 52 & 64 & 76 & 85 \\
\hline
\end{tabular}

8-3 Brotos

C/A $\quad 133,55$ a $\quad .359,48$ a $\quad 430,30$ a $\quad 452,25$ a $\quad 516,03$ a

2-S/desbro-

ta C/A $\quad 114,39$ ab 301,67 a $\quad 344,00$ a $\quad 366,97, a \quad 425,90$ a

$6-2$ brotos

C/A 108,93 ab 263,61 a 309,55 a 334,12 a 381,39 a

4-1 1 broto

C/A $\quad 86,85$ ab 254,31 a $\quad 293,60$ a $\quad 320,58$ a 374,48 a

7-3 brotos

S/A $\quad 91,85$ ab 251,27 a $\quad 284,24$ a $\quad 320,03$ a 372,88 a

$5-2$ brotos

S/A $\quad 77,57$ b 222,54 a $\quad 261,70$ a 287,36 a 331,36 a

1-S/desbrota

S/A $\quad 88,69$ ab $\quad 203,62$ a $\quad 251,28$ a $\quad 265,77$ a 313,27 a

3-1 Broto S/A 58,92 b $\quad 182,45$ a $\quad 242,74$ a 253,06 a $\quad 292,76$ a

\begin{tabular}{lrrrrr}
\hline Mëdia & 94,34 & 254,88 & 302,18 & 325,02 & 374,76 \\
C.V. $(\%)$ & 20,48 & 25,22 & 24,40 & 23,70 & 23,34 \\
\hline
\end{tabular}


A Tabela 13 apresenta os contrastes entre as médias dos tratamentos, da variāvel volume cilīndrico, aos 85 meses de $\ddot{i d a d e .}$

Tabela 13 - Comparação entre médias de volume cilīndrico $\left(\mathrm{m}^{3} / \mathrm{ha}\right)$ dos tra tamentos.

\begin{tabular}{lrc}
\hline Fertilização & Volume cilindrico $\left(\mathrm{m}^{3} / \mathrm{ha}\right)$ & Volume cilíndrico (\%) \\
\hline $0 \mathrm{~g} /$ touça & $327,57 \mathrm{~b}$ & $\begin{array}{l}100,00 \\
128,81\end{array}$ \\
$300 \mathrm{~g} /$ touça & $421,95 \mathrm{a}$ & 190 \\
\hline Condução da touça & Volume cilindrico $\left(\mathrm{m}^{3} / \mathrm{ha}\right)$ & Volume cilinárico (\%) \\
\hline Sem desbrota & $364,58 \mathrm{a}$ & 109,28 \\
1 broto/touça & $333,62 \mathrm{a}$ & 100,00 \\
2 brotos/touça & $356,38 \mathrm{a}$ & 106,82 \\
3 brotos/touça & $444,46 \mathrm{~b}$ & 133,22 \\
\hline
\end{tabular}

A Figura 8 representa o comportamento do cres cimento volumétrico. 


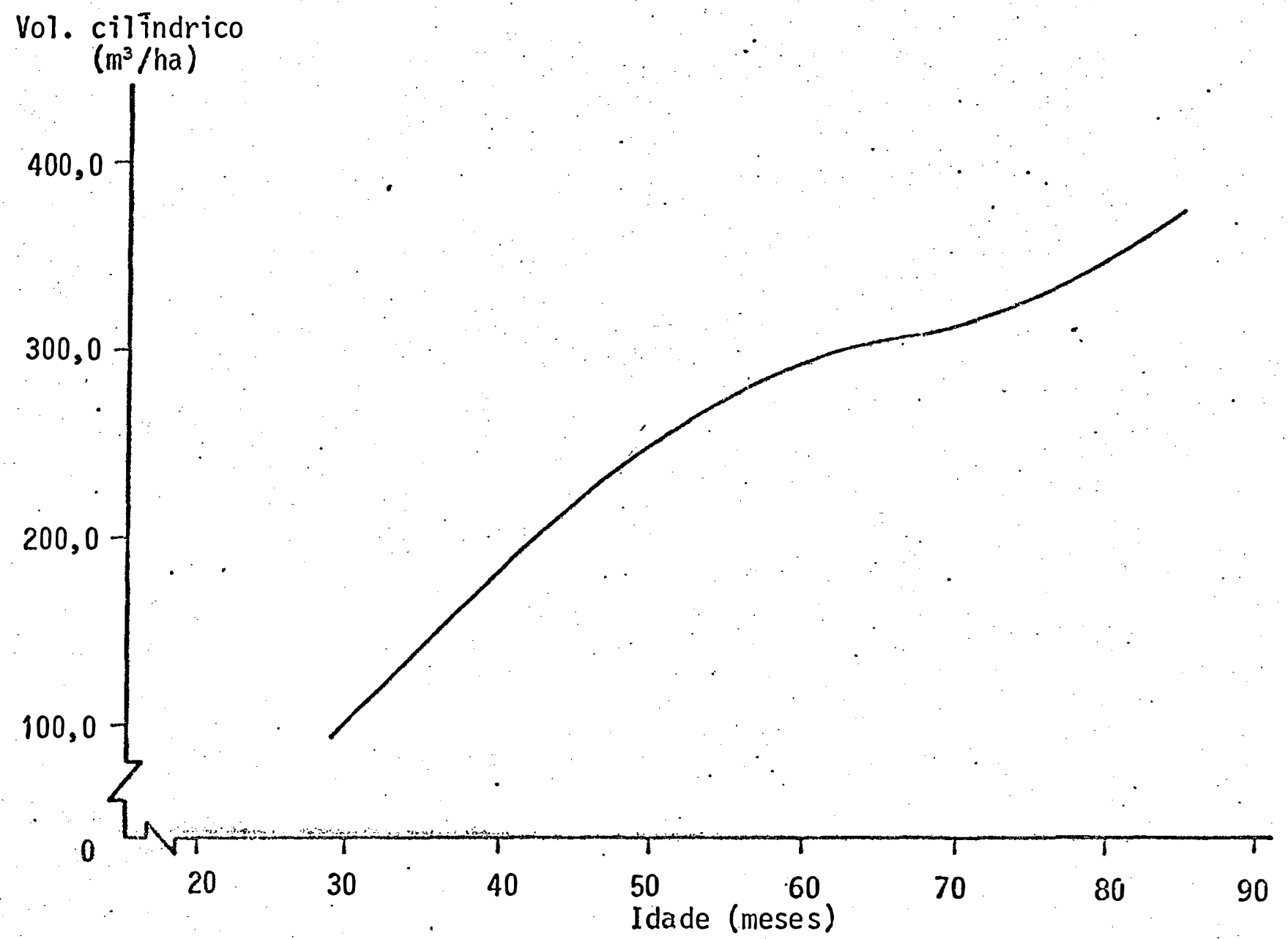

Figura 8 - Curva de crescimento do volume cilindrico $\left(\mathrm{m}^{3} / \mathrm{ha}\right)$ dos brotos em função da idade.

A Figura 9 representa o crescimento médio em volume cilindrico, em função do nümero de brotos por touça. 


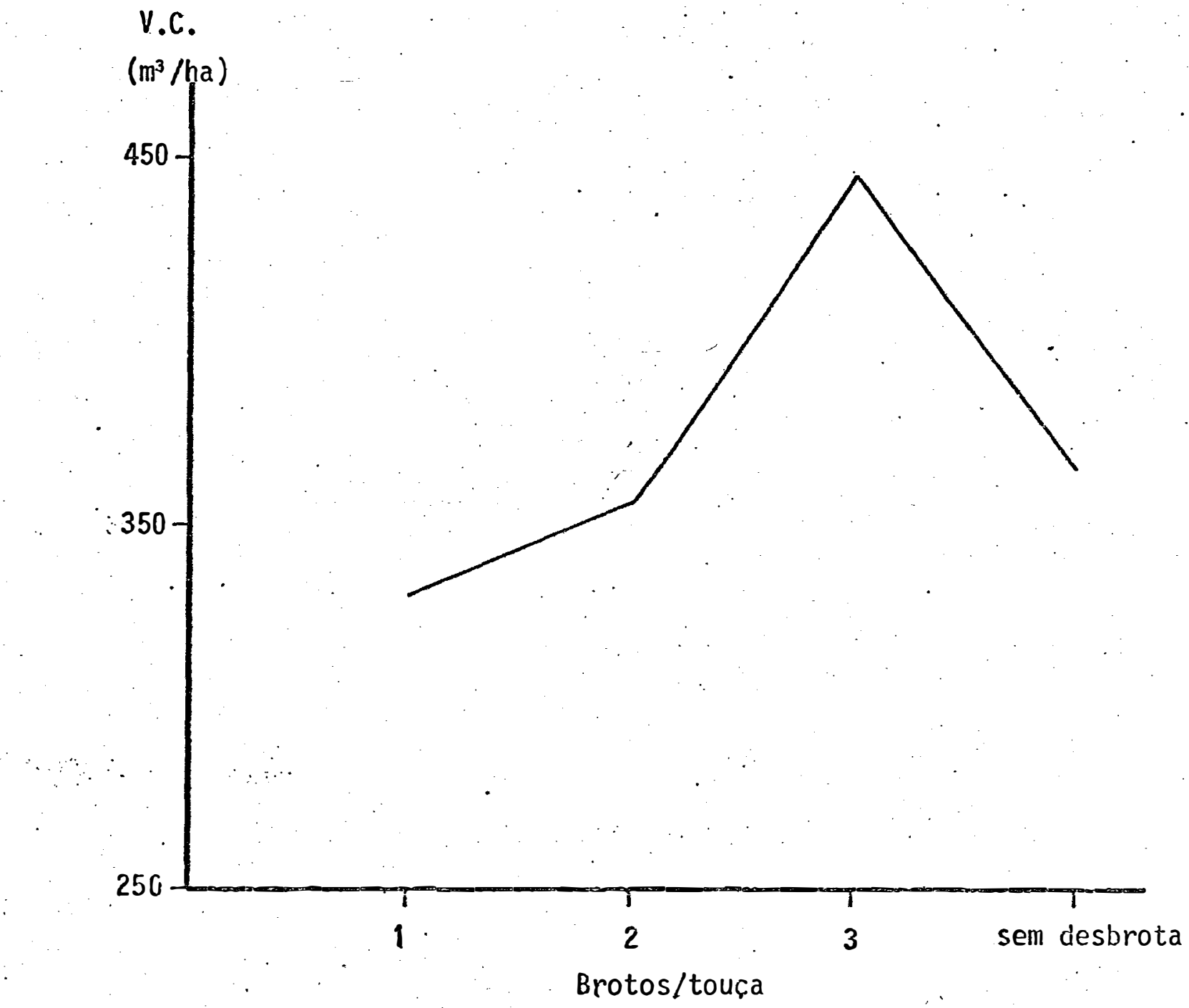

Figura 9 - Volume cilindrico ( $\mathrm{m}^{3} / \mathrm{ha}$ ) dos brotos em função do número de brotos por touça.

As comparacões entre os volumes mètios dos tra tamentos não mostraram diferencas significativas entre eles, da segunda $\bar{a} \cdot \bar{u} 7$ tima medição.

Entretanto, o volume cilindrico foi crescente 
naqueles tratamentos que receberam adubacão e seus valores são iguais ou superiores à média. Houve ainda, uma tendēncia de incremento do volume conforme ia-se incrementando o nūmero de brotos nos tratamentos desbrotados.

A diferença em produção (com base no volume ci Iindrico) entre os tratamentos adubados e não adubados é con siderada a seguir:

Tratamentos Volume cilindrico $\left(\mathrm{m}^{3} / \mathrm{ha}\right) \quad$ Diferença $\left(\mathrm{m}^{3} / \mathrm{ha}\right)$

\begin{tabular}{|c|c|c|c|}
\hline $8-7$ & $516,03-372,88$ & $=$ & 143,15 \\
\hline $6-5$ & $381,39-331,36$ & $=$ & 50,03 \\
\hline $4-3$ & $374,48-292,76$ & $=$ & 81,72 \\
\hline $2-1$ & $415,90-313,27$ & $=$ & 102,63 \\
\hline
\end{tabular}

Verifica-se assim que as diferencas de volume produzido entre os tratamentos adubados e não adubados permi te obter de $50,03 \mathrm{~m}^{3} / \mathrm{ha}$ até $143,15 \mathrm{~m}^{3} / \mathrm{ha}$ a mais de producão, dependendo do número de brotos por touca. Em alguns casos, como nos tratamentos 8 e 7 , o volume foi $38 \%$ maior.

o coeficiente de variação subiu sensivelmente mas ainda se mantém em nīveis aceitāveis.

Na Figura 8 observa-se uma reducão no crescimento da 3 ạ para a 4 ạ medição, observando-se também um aumen to acentuado no crescimento da 4 a para a 5 ạ medịcão em decor 
rência do discutido na Figura 4.

Pode-se observar na Tabela 13 que houve diferença signifícativa ao nivel de $5 \%$ para os contrastes de adu bação, sendo favorável para os tratamentos adubados uma supe rioridade da ordem de $28,81 \%$.

Pára os tratamentos de desbrota não apresentaram diferenças significativas entre eles, no entanto o tra tamento 3 brotos por touca, apresenta uma superioridade da ordem de $33,22 \%$ quando comparado ao tratamento 1 broto por touça.

A Figura 9 apresenta o mesmo comportamento que a Figura 7., ou seja um aumento do volume cilindrico com o au mento do número de brotos por touça, até o tratamento de 3 brotos por touca diminuindo a partir da $\hat{i}$ quando se aumenta o nüinero de brotos.

\subsection{SOBREVIVENCIA}

A Tabela 14 apresenta as médias dos dados não transformados do número de touças sobreviventes por parcela a porcentagem de sobreviventes e os dados de falhas transfor mados em arco seno $\sqrt{\text { no de falhas }+0,5}$. 
Tabe la 14 - Resultados médios da sobrevivência de Eucalyptus saligna Snith, aos 85 meses cie idade. (agosto 1985).

\begin{tabular}{lccc}
\hline Tratamentos & $\begin{array}{c}\text { Dados:não } \\
\text { transformados }\end{array}$ & $\begin{array}{c}\text { Porcentagem } \\
\text { de } \\
\text { sobreviventes }\end{array}$ & $\begin{array}{c}\text { Dados } \\
\text { transformados } \\
\text { de falhas }\end{array}$ \\
\hline 1-S/desbrota S/A & 35,33 & 72,11 & 32,16 \\
2-S/desbrota CA & 36,00 & 73,47 & 31,11 \\
3-1 broto S/A & 35,33 & 72,11 & 32,16 \\
4-1 broto C/A & 35,00 & 71,43 & 32,50 \\
$5-2$ brotos S/A & 30,67 & 62,59 & 38,01 \\
6-2 brotos C/A & 34,00 & 69,39 & 33,80 \\
$7-3$ brotos S/A & 33,33 & 68,03 & 34,68 \\
8-3 brotos C/A & 36,00 & 73,47 & 31,32 \\
\hline Média & 34,46 & 70,33 & 33,22 \\
\hline
\end{tabular}

A anālise estatîstica não revelou diferença significativa entre os tratamentos, quanto ao nümero de toucas sobreviventes.

A porcentagem média de sobrevivência no experimento foi $70,33 \%$. Embora não tenha havido diferença significativa entre os tratamentos, pode-se observar uma porcenta gem considerável de fálhas nas brotacões, as qua is diferem em $11,23 \%$ e $13,52 \%$, dos encontrados por SIMOES et alii (1972) 
e de COUTO (1973), respectivamente. Estes autores verificaram falhas nas brotacões de Eucalyptus saligna Smi.th, no estado de São Ṕaulo, na ordem de $40,94 \%$ e $43,19 \%$, respectivamente.

Era de se esperar que com o correr do tempo, apōs a desbrota, a porcentagem de falhas aumentasse, principalmente, no tratamento onde foi deixado um só broto, em decorrência dos danos causados primordialmente pelo vento (que bra das brotações). Porēm isto não ocorreu devendo-se, talvez, a que na época da desbrota (16 meses após o corte), as brotaçoes se encontravam suficientemente fortes, bem implantadas e vigorosas para suportar as acões mecânicas do vento.

\subsection{Aiválise de CöVARIẤnCIA do DAP_, ALTURA E VOLUME CILÍN DRICO}

As. Tabelas 15,16 e 17 apresentam os ajustamentos das médias do DAP, altura e volume cilindrico por he tare em função do nümero de touças sobreviventes. A Tabela 18 apresenta a comparacão entre as médias dos tratamentos. 
Tabela 15 - Ajustamento das médias de DAP em função do número de touças sobreviventes de Eucalyptus saligna Smith, aos 85 meses de idäde (agosto 1985).

Médias de tratamentos

Tratamento

$\frac{\text { Originais }}{Y} \quad$ Ajustadas

1-S/desbrota S/A

6,407

35,333

6.388

3-1 broto S/A

10,364

35,333

10,345

5-2 brotos S/A

9,046

30,667

9,128

7-3 brotos S/A

7,696

33,333

7,721

2-S/desbrota C/A

7,262

36,000

7,229

4-1 broto C/A

11,771

35,000

11,759

6-2 brotos C/A

8,973

34,000

8,983

8-3 brotos C/A

8.754

36,000

8,721

Média

8,784

34,46

8,784 
Tabela 16 - Ajustamento das médias de altura em função do nūmero de tou ças sobreviventes de Eucalyptus saligna Smith, aos 85 meses de idade.

Mèdias dos tratamentos

Tratamento

\begin{tabular}{|c|c|c|}
\hline \multicolumn{2}{|c|}{ Originais } & Ajustadas \\
\hline$Y$ & $x$ & $Y$ ajust. \\
\hline
\end{tabular}

1-S/desbrota S/A

10,865

35,333

10,801

3-1 broto $S / A$

14,839

35,333

14,774

5-2 brotos S/A

13,684

30,667

13,963

7-3 brotos S/A

12,270

33,333

12,353

2-S/desbrota C/A

12,572

36,000

12,459

4-1 broto C/A

16,457

35,000

16,417

6-2 brotos C/A

14,088

34,000

14,122

8-3 brotos C/A

14,185

36,000

14,072

Média

13,62

34,46

13,620 
Tabela 17 - Ajustamento das médias de volume cilinndrico por hectare, em funcão das touças sobrevivențes de Eucalyptus saligna Smith.

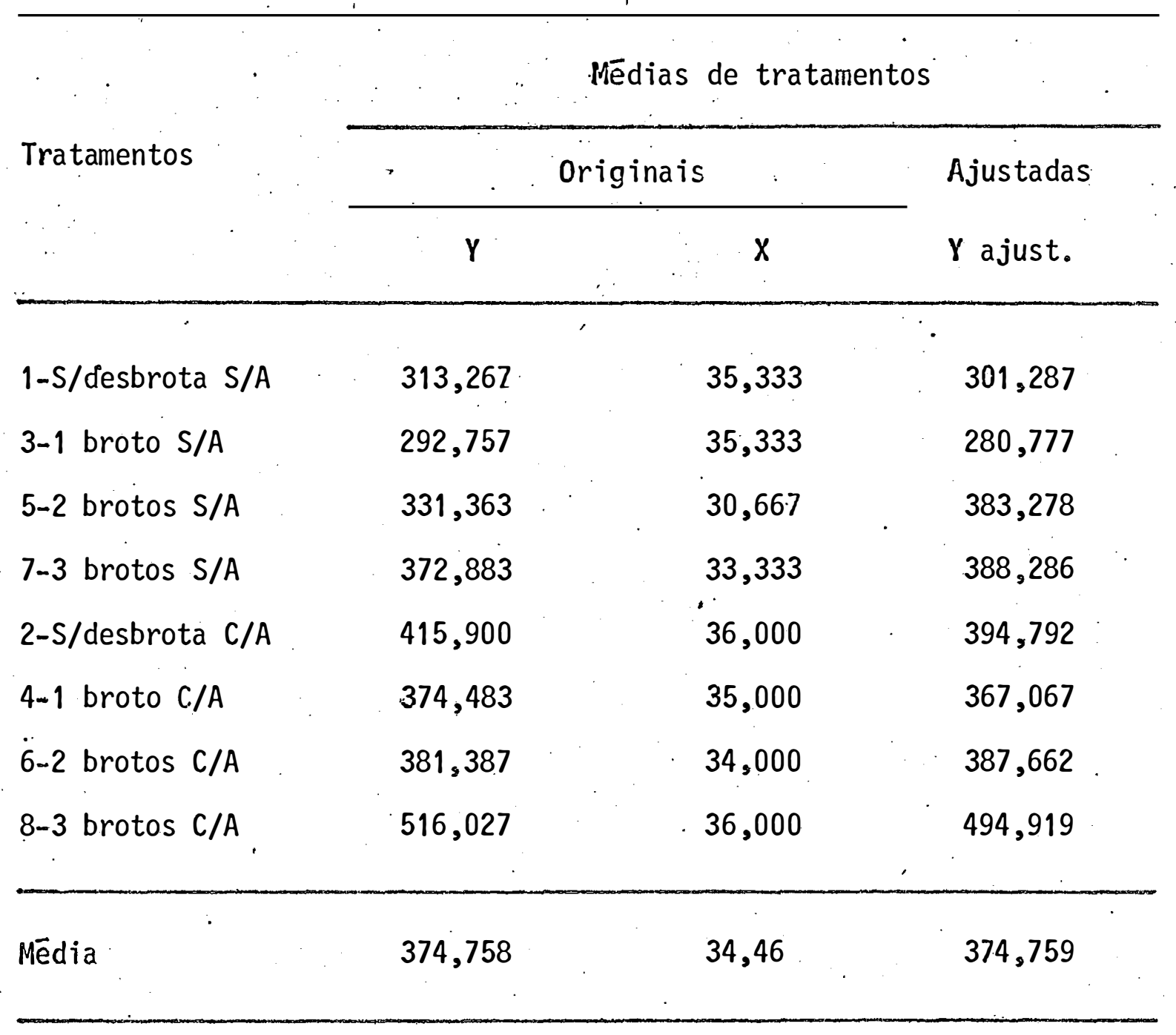


Tabela 18 - Comparação, pelo teste de Tukey, das médias ajustadas das va riāveis DAP, altura e volume cilinndrico, dos brotos das tou cas de Eucalyptus saligna Smith, aos 85 meses de idade.

No Tratamento ' No de touças $x$ No de touças $x$ No de touças $x$ altura média. 'DAP médio. volume cilinndrico

\begin{tabular}{lllll}
\hline 4 & 1 broto C/A & $16,42 \mathrm{a}$ & $11,76 \mathrm{a}^{*}$ & $367,07 \mathrm{a}$ \\
3 & 1 broto S/A & $14,77 \mathrm{ab}$ & $10,35 \mathrm{ab}$ & $280,78 \mathrm{a}$ \\
6 & 2 brotos C/A & $14,12 \mathrm{ab}$ & $8,98 \mathrm{bc}$ & $387,66 \mathrm{a}$ \\
8 & 3 brotos C/A & $14,07 \mathrm{ab}$ & $8,72 \mathrm{bc}$ & $494,92 \mathrm{a}$ \\
5 & 2 brotos S/A & $13,96 \mathrm{ab}$ & $9,13 \mathrm{bc}$ & $383,28 \mathrm{a}$ \\
2 & s/desbrota C/A & $12,46 \mathrm{bc}$ & $7,23 \mathrm{~cd}$ & $394,79 \mathrm{a}$ \\
7 & 3 brotọ S/A & $12,35 \mathrm{bc}$ & $7,72 \mathrm{c}$ & $388,29 \mathrm{a}$ \\
1 & s/desbrota S/A & $10,80 \mathrm{c}$ & $6,39 \mathrm{~d}$ & $301,29 \mathrm{a}$ \\
\hline & & 13,62 & 8,79 & 374,76
\end{tabular}

* Os valores com a mesma letra não diferem significativamente a $5 \%$ de probabilidade.

Segundo a Tabela 18, a anālise de covariāncia revela haver diferenca significativa ao nivel de $5 \%$ de proba bilidade entre as alturas médias quando comparados os trata mentos 4 contra os tratamentos 2,7 e 1 , e quando compara- 
dos os tratamentos $4,3,6,8$ e 5 contra o tratamento 1 .

Para o caso do DAP médio as diferenças signi-

ficativas föram reveladas para os contrastes entre as :médias dos tratamentos 4 contra $5,6,8,7,2$ e 1 ; sendo 7,2 e 1 inferiores a 4 e 3 e 1 o menor de todos.

Desse modo, os tratamentos 4 e 3 , mostraram ser os melhores para altura e diãmetro, sendo seguidos pelos. tratamentos 6,8 e 5 .

No caso do volúme cilindrico não houve diferença entre os contrastes das médias dos tratamentos.

Para o volume cilindrico, ainda que não houve diferenca significativa entre os contrastes, os tratamentos salientes foram: 8 ( 3 brotos com adubação) e 2 (sem desbrota com adubação). Verifica-se, assim, uma tendēncia do vo lume total aumentar com o aumento do nümero de brotos e com a adubação.

\subsection{FAtORES DE FORMA E DE EMPILHAMENTO}

A Tabela 19 apresenta os fatores de forma total e da parte comercial das ārvores, com casca e sem casca, e o fator de empilhamento para Eucalyptus saligna Smith, aos 85 meses de idade (agosto 1985). 
Tabela 19 - Fatores de forma e de empithamento para Eucalyptus saligna Smith, à idade de 85 meses.

\begin{tabular}{|c|c|c|c|c|c|}
\hline Tratamentos & $\begin{array}{c}F . F . \\
\text { comercial } \\
\text { cc }\end{array}$ & $\begin{array}{c}\text { F.F. } \\
\text { sc }\end{array}$ & $\begin{array}{l}F . F \\
\text { total } \\
\text { CC }\end{array}$ & $\begin{array}{l}\text { F.F. } \\
\text { total } \\
\text { SC }\end{array}$ & F.E. \\
\hline 1-S/desbrota S/A & 0,51 & 0,40 & 0,56 & 0,44 & 1,60 \\
\hline 2-S/desbrota C/A & 0,47 & 0,37 & 0,54 & 0,42 & 1,66 \\
\hline 3-1 broto $S / A$ & 0,52 & 0,42 & 0,54 & 0,44 & $1 ; 53$ \\
\hline 4-1 broto $\mathrm{C} / \mathrm{A}$ & 0,50 & 0,40 & 0,52 & 0,42 & 1,52 \\
\hline $5-2$ brotos S/A & 0,51 & 0,41 & 0,55 & 0,44 & 1,56 \\
\hline $6-2$ brotos $\mathrm{C} / \mathrm{A}$ & 0,52 & 0,42 & 0,55 & 0,44 & 1,57 \\
\hline $7-3$ brotos S/A & 0,52 & $0,41^{\prime}$ & 0,57 & 0,44 & 1,54 \\
\hline $8-3$ brotos $\mathrm{C} / \mathrm{A}$ & 0,52 & 0,42 & 0,55 & 0,45 & 1,59 \\
\hline Média & 0,51 & 0,41 & 0,55 & 0,44 & 1,57 \\
\hline
\end{tabular}

$$
\begin{aligned}
F_{. F} & =\text { fator de forma } \\
c c & =\text { com casca } \\
\text { SC } & =\text { sem casca } \\
\text { F.E. } & \text { fator de empilhamento }
\end{aligned}
$$




\subsection{DENSIDADE BÁSICA MÉdIA; PORCENTAGEM DE CASCA, VOLURE DE MADEIRA EMPILHADA E PESO DE MADEIRA SECA}

A Tabela 20 mostra os dados da densidade bás ca média das hastes, a porcentagem de casca, o volume total de madeira empilha'da com casca resultante do corte raso e a estimativa do peso de madeira seca sem casca de Eucalyptus sa ligna Smith aos 85 meses de idade, nos diversos tratamentos.

Tabela 20 - Densidade básica média, porcentagem de casca, volume de madeira empilhada e produção de madeira seca em peso, aos 85 meses de idade.

\begin{tabular}{|c|c|c|c|c|}
\hline Tratamentos & $\begin{array}{l}\text { Densidade } \\
\text { bāsica } \\
\text { média } \\
\left(\mathrm{kg} / \mathrm{m}^{3}\right)\end{array}$ & $\begin{array}{c}\text { Casca. } \\
(\%)\end{array}$ & $\begin{array}{l}\text { Volume de } \\
\text { madeira } \\
\text { empilhada } \\
\text { (st/ha) }\end{array}$ & $\begin{array}{c}\text { Produção de } \\
\text { matêria } \\
\text { seca } \\
(t / h a)\end{array}$ \\
\hline
\end{tabular}

8-3 brotos C/A 512,50 â $\quad 24.78$ a $\quad 394,78$ a $\quad 144,44$ a

2-S/desbrota C/A 518,13 a $\quad 28,10$ a 317,74 ab, 117,07 a

6-2 brotos C/A $\quad 510,50$ a $\quad 27,59$ a 283,26 ab $\quad 106,63$ a

7-3 brotos S/A 514,30 a $\quad 28,08$ a 267,95 ab 107,51 a

4-1 broto C/A $\quad 520,07$ a $\quad 26,29$ a $\quad 259,92$ ab $\quad 102,15$ a

$\begin{array}{lllll}5-2 \text { brotos S/A } & 513,77 \text { a } & 27,30 \text { a } & 259,68 \text { ab } & 94,06 \text { a }\end{array}$

1-S/desbrota S/A 513,97 a 27,86 a 241,72 ab $\quad 90,02$ a

3-1 broto S/A $\quad 518,03$ a 26,08 a 226,00 b $\quad 82,19$ a

Média $\quad 515,16 \quad 27,01 \quad 281,38 \quad 105,51$

C.V. $(\%) \quad 1,53 \quad 6,81: 19,92.21,90$


As médias dos tratamentos para densidade bāsi ca, produção de madeira em peso e porcentagem de casca, não apresentaram diferencas significativas entre eles.

Para o volume empilhadosó foi encontrada uma diferenca significativa quando comparados aos tratamentos 8 e 3 .

A densidade básica média apresentou cómo valo res extremos $510,5 \mathrm{~kg} / \mathrm{m}^{3}$ no tratamento 6 e $520,07 \mathrm{~kg} / \mathrm{m}^{3}$ no tratamento 4 e uma mëdia de $515,16 \mathrm{~kg} / \mathrm{m}^{3}$.

As médias para porcentagem de casca variaram de $24,78 \%$ no tratamento 8 a $28,10 \%$ no tratamento 2 , àpresentando uma média de $27,01 \%$.

Quanto ao volume empilhado, as médias obtidas variaram de 226,0 esteres/ha no tratamento 3 a 394,74 esteres/ha no tratamento 8 e a média dos tratamentos foide 281,38 esteres/ha.

A producão de madeira seca na segunda rotacão variou de 82,19 t/ha no tratamento 3 a 144,44 t/ha no tratamento 8 , sendo a média 105,51 t/ha, aos 7 anos de idade. 
5. CONCLUSÕES

Com base na discussão dos resultados obtidos pode-se concluir que:

1. A altura média das brotações foi inversamente proporcional ao nümero de brotos por touca.

2. A adubação influenciou positivamente na altura dos brotos das toucas.

3. O DAP médio das brotações foi influenciado pelo nūmero de brotos, ocorrendo os maiores diâmetros nos tratamentos com um sō broto por touca.

4. A adubação influenciou significativamente 0 crescimento em diâmetro das brotąões. 
5. 0 nümero de brotos influenciou diretamente a expressão da ārea basal, sendo maior nos tratamentos com maior número de brotos.

6. A adubação tambēm influenciou significativamente a área büsait.

7. 0 volume cilindrico foi influenciado positivamente pela adubação e pelo número de brotos.

8. A sobrevivência das touças não foi afetada significativa mente pelo nūmero de brotos nem pela adubação.

9. A densidade básica da madeira não sofreu alterações significativas em função da fertilização ou do nümero de brotos.

10. 0 volume final de madeira cortada e empilhada para chapas de fibra foi beneficiado pelo número de brotos e pela adubação.

11. Os três melhores tratamentos em produção de madeira empi Thada foram os seguintes: 8 ( 3 brotos, com adubação), 2 (sem desbrota, com adubação) e 6 (2 brotos, com adubacão) com 394,$78 ; 317,74$ e 283,26 esteres/ha, respectivamente. 0 pior tratamento foi 1 broto, sem adubação. 
12. A produção em peso cie madeira seca na segunda rotação não foi influenciada significativamente pela adubação e pelo nūmero de brotos por touca. Entretanto os tratamentos com maior nūmero de brotos e com adubação estão acima da mēdia que é de $105,5 \mathrm{t} / \mathrm{ha}$. A maior produção foi obtida no tratamento 8 ( 3 brotos, com adubação) com 144,44 t/ha e a menor no 3 ( 1 broto, sem adubacão) com 82,19 t/ha de ma deira seca. 


\section{LITERATURA CITADA}

ALBINO, J.C., 1983. Características de crescimento e variação da densidade básica da madeira em doze espécies de Eucalyptus em trēs regiões do estado de Minas Gerais. Piracicaba, 90p. [Dissertação de Mestrado].

ANDRADE, E.N., 1961. O eucalipto. 2.ed. Companhia Paurista de Estradas de Ferro, Jundiaí, 667p.

ASSOCIACAO TECNICA BRASILEIRA DE CELULOSE E PAPEL, 1974. Normas de ensaio. Rio de Janeiro.

BAENA, E. de S.; A.L. MORA; G. BERTOLOTI E R.S. OSORIO, 1983. is Efeitos de algumas prāticas silviculturais na brotação de Eucalyptus saligna Smith. In: Simpōsio IUFRO: Em Melhoramento Genētico e Produtividade de Espécies Florestais de Rāpido Crescimento. Anais. Silvicultura. São Paulo, 4(32): 617-620. 
BALLONI, E.A. e P.A. SILVA, 1978. Conducão de toucas de Eucalyptus: Resultados preliminares. Boletim informativo, IPEE. Piracicaba, $6(16): b_{q}-b_{8}$.

BALLONI, E.A.; J.W. SIMOES e P.A. SILVA, 1978. Condução de touças de eucalipto. Silvicultura. São Paulo, 2 (14): 87-89.

BARRET, R.L.; D.T. CARTER e B.R.T. SEUWARD, 1975. Eucalyptus grandis in Rhodesia. The Rhodesia bulletin of forest research. Salisbury, (6): $1-87$.

BARROS, N.F.; J.M. BRAGA; R.M. BRANDI e B.V. DE FELLIPO, 1978 . Efeito de nîveis de fertilizantes minerais na producão de Eucalyptus em solos de Cerrado de Minas Gerais. SIF. Vicosá. 12p. [Boletim técnico nọ 1].

BARROS, N.F., 1982. Adubação mineral de plantios florestais. In: Seminärio: Reflorestamento no Nordeste Semi-ärido, EMBRAPA/IBDF. Documentos no 18. p.55-72.

BARRICHELL 0, L.E.G. e J.0.BRITO, 1978, A madeira de Pinus taeda como matéria-prima para celulose kraft. I. Influēncia dos teores de lenhos. In: Congresso florestal Brasileiro, Manaus, (3): 1-18. 
BARRICHELLO, L.E.G. e J.0. BRITO, 1979. A utilização da madeira na producão de celulose. Circular técnica. IPEF. Piracicaba, (68): 1-16.

BARRICHELLO, L.E.G., 1980. Pinus caribaea var. hondurensis. Principais interacões entre as caracterïsticas da madeira e orendimento e qualidade da celulose. Circular técnica. IPEF. Piracicaba, (86): 1-10.

BARRICHELLO,L.E.G.; J.O. BRITO; H.T.Z. COUTO E E. CAMPINHOS Jr., 1980. Densidade bāsica, teor de holocelulose e réndimento em celulose de madeira de Eucalyptus grandis. In: Simpósio IUfRo: Em Melhoramento Genētico e Produtividade. de espécies de rāpido crescimento, Aguas de São Pedro. p.11.

BAULE, H. e C. FRICKER, 1970. The fertilizer treatment of forest trees. Munich, B.L.V. Verlagsgesellschaft. 259 p.

- BEATON, J.D.; 1973. Fertilizer methods and applications to foresty practice. In: Forest Fertilization symp. Proc., US. Dep. Agr. Forest Service General Tech. Rep. NE-3-5571. 
BLAIR, R.L.; B.J. ZOBEL e J.A.BARKER, 1975. Prediction of gain in pulp yield and tear strenght. in young loblolly pine through genetic increases in wood density. TAPPI. Atlanta, 58(1): 89-91.

BRAGA, J.M. E D. ROCHA, 1979. Estudos de adubação fosfatada na cultura de Eucalyptus em solos de cerrado de Minas Gerais. In: Seminārio. SIF: Fertilização e Melhoramento florestal, 10, Belo Horizonte, Anais. SIF. Vicosa, p.1-4.

BRASIL, M.A.M. e M. FERREIRA, 19Z . Variação da densidade bāsica da madeira de Eucalyptus alba Reinw, E. saligna Smith, E. grandis Hill ex Maiden aos 5 anos de idade, em função do local e espacamento. IPEF, (2/3): 129-149.

BRASIL, M.A.M.; R.A.A. VEIGA e H. do A. MELLO, 1979. Densidade básica da madeira de Eucalyptus grandis Hill ex Maiden, aos 3 anos de idade. IPEF. Piracicaba, (19): 63-76.

BRITO, J.0. e L.E.G. BARRICHELLO, 1977: Correlações entre caracteristicas físicas e químicas da madeira e a produça de carvão vegetal. I. Densidade e teor de lignina na madeira de eucalipto. IPEF. Piracicaba $5(4): 19-28$. 
BRITO, J.O. e L.E.G. BARRICHELLO, 1979. Aspectos florestais e tecnológicos da matéria-prima para carvão vegetal. Circular técnica. IPEF. Piracicaba, (67): 1-4.

BRITO, J.0. e L.E.G. BARRICHELLO, 1980. Correlacões entre características físicas e químicas da madeira e a producão de carvão: densidade da madeira $x$ densidade do carvão. IPEF. Piracicabais (20): 121-126.

BROWING, B.L., 1963. The chemistry of wood. New York, Interscience Publishers, John Wiley \& Sons. 689p.

CARVALHO, C.M., 1973. Nota prévia sobre alguns problemas na fertilização de Eucalyptus saligna Smith (Deficiência de B. $\mathrm{Zn}$ e $\mathrm{Cu})$. II Congresso Florestal Brasileiro, Curitiba, p.128-129.

COMISSAO DE SOLOS, 1960. Levantamento de recohecimento dos Solos do Estado de São Paulo. C.N.E.P.A. Serviço Nacional de Pesquisa Agronōmica. Boletim 12. 634p.

COUTO, H.T.Z. do, 1973. Condução da brotação de Eucalyptus saligna Smith com 1,2 e 3 brotos por touca. Piracicaba, ESALQ, 51p. [Dissertação de Mestrado]. 
DE FELLIPO, B.V.; V.H. ALVAREZ; L. COUTO E J.C. FERNANDEZ, 1979. Estudos de micronutrientes em plantacões de eucalipto em solos de cerrado de Minas Gerais. In: Seminārio SIF: Fertilização e Melhoramento florestal, 10, Belo Horizonte. Anais. SIF. Vicosa, p.15-26.

ERICKSON, H.D. e G.M.B. LAMBERT, 1958. Effects of fertilization and thinning on chemical composition, growth and specific gravity of yuong douglas-fir. Forest science. Washington, $\underline{4}(4): 307-15$.

FAO, 1981. El Eucalipto en la repoblación forestal. Roma. $694 p$.

FERREIRA, M., 1968. Estudo da variação da densidade básica da madeira de Eucalyptus alba Reinw e Eucalyptus saligna Smith. Piracicaba, ESALQ. [Tese de Doutoramento].

FERREIRA, M., 1970. Estudo da variação da densidade bāsica da madeira de povoamento de Eucalyptus grandis Hill ex Maiden. Piracicaba, ESALQ-USP, 62p. [Tese de Livre-Docência].

FERREIRA; M. e P.Y. KAGEYAIMA, 1978. Melhoramento genētico da densidade de madeira de eucalipto. In: Congresso florestal Brasileiro, III. Silvicultura. São Paulo, 14: 148-152. 
FOELKEL, C.E.B.; M.A.M. BRASIL e L.E.G. BARRICHELLO, 1971. Mètodo para a determinação da densidade bäsica de cavacos para coniferas e folhosas. IPEF. Piracicaba, (2/3): $65-74$.

FOELKEL, C.E.B. e L.E.G.BARRICHELLO, 1975. Tecnologia de celulose e papel. CALQ. Piracicaba, 207 .

FOELKEL, C.E.B.; W. GARCIA; J.H. NEHRING; A.S. DINIZ e J.V. GONZAGA, 1980. Pinus elliottii: fibra longa para producão de celulose kraft. In: Simpósio IUFRo em Melhoramento Genētico e Produtividade de Espécies Florestais de Rápido Crescimento. Águas de São Pedro, 25-30 agosto. 50p.

GOMES, F.P., 1970. Curso de estatistica experimental. 4.ed. São Paulo, Livraria Nobel.

GONCALVES, J.C. e A.S. DINIZ, 1981. Efeito da'época e forma de aplicação de fertilizantes no plantio de Eucalyptus saligna. Boletim informativo IPEF. Piracicaba, 9 (28): 21-23.

HAAG, H.P., Coord., 1983. Nutrição mineral de Eucalyptus, Pinus, Araucaria e Gmelina no Brasil. Fundação Cargill. Campinas, SP. $101 \mathrm{p}$. 
HARRIS, J.M.: R.N. JAMES E M.J. COLLINS, 1976. Case for improving wood density in radiata pine. New Zealand. Journal of florestry science. Rotoruas $5(3): 347-354$.

JANKOWSKY, I:P., 1979. Madeira juvenil, formação e aproveitamento industrial. Circular técnica IPEF. Piracicaba, $(81): 1-18$.

JUVILLAR, J.B., 1979. O carvoejamento da madeira e seus refie.xos na qualidade do carvão: Qualidade da madeira. Piracicaba, IPEF. 8p: [Circuiar técnica, 64].

JUVILLAR, J.B., 1980. Tecnologia de transformacão da madeira. In: PENEDO, W.R., ed. Uso da madeira para fins energēticos. Belo Horizonte, CETEC/SPT-001. p.69-82.

KLEM, G.S., 1968. Quality of wood from fertilized forest. TAPPI. Atlanta, 51(11): 99A-103A.

MAGALHAES NETO, J.L., 1980. Potencial de culturas perenes para a região dos cerrados: florestas. In: Simpōsio sobre o cerrado: uso e manejo. Brasilia, Editerra. p.355-370. 竞

MAGALHAES, J.G.R., 1980. Tecnologia de obtenção de madeira. In: PENEDO, W.R. ed. Uso da madeira para fins energéticos. Belo. Horizonte, CETEC/SPT-00१. p.56-66. 
MELLO, H.A.; J. MASCARENHAS SOBRINHO; J.W. SIMOEES E H.T.Z. do COUTO, 1970. Resultados da aplcação de fertilizantes minerais nã produção de madeira de Eucalyptus saligna $\mathrm{Sm}$, em solos de cerrado do Estado de São Paulo. IPEF. Piracicaba, (1): $7-26$.

MENDES, C.J.; W. SUITER Fo; G.C, de REZENDE e T.S. de A. MORAES, 1980. Técnicas de Corte e Manejo da Broțação em Plantio de Eucalyptus urophylla (hibrido de Rio Claro) em fásès de primeiro e segundo corte. In: Simpósio IUfRo em MeIhoramento Genético e Produtividade de Espécies Florestais de Rāpido Crescimento. Silvicultura. São Paulo, (16): 68 . [Edição Especial].

MORA, A.L. e G. BERTOLOTI, 1979. Boletim informativo da região Centro-Sul. Boletim informativo. IPEF. Piracicaba, $\underline{7}(22): 1-40$.

NYLINDER, P., 1965. Non destructive field sampling systems for determining the wood density of standing timber over large areas, variations within and between species an the influence of environmental and other fator of wood density. In: IUFRO Meeting Section 41, Melbourne 1965: Proceedings Melbourne, CSIRO, V.1: 1-13. 
PAIVA, H.N. de; F. de FAULA HETO; R.M. BRANDI e A.B. VALE, 1983. Influencia das idades de corte e de desbrota e do número de brotos sobre o desenvolvimento da brotação de cepas de Eucalyptus spp. Revista Arvore, I(1): 1-10.

PEREIRA, A.R。; F. de PAULA NETO; e L.R. RAMALHO; 1980. Determinação do nūmero de brotos em brotações de Eucalyptus spp. Vicosa, SIF. 11p. [Boletim Técnico nọ 10].

- PEREIRA, A.R. e H.P. LADEIRA, 1983. Custos de desbrota em povoamentos de Eucalyptus. In: Congresso Florestal Brasileiro, 49, Belo Horizonte. Anais. Silvicultura, São Paulo, p. $422-423$.

POYNTON, R.J., 1983. The silvicultural treatment of eucalipt plantations in Southern. Africa. In: Simposio IUfRo em MeThoramento Genético e Produtividade de Espēcies Florestais de Rāpido Crescimento. Anais. Silvicultura. São Paulo, $3(31): 603-605$.

REZENDE, G.C.; W. SUITER F.o e.C.J. MENDES, 1980. Regeneracão de maciços florestais da Cia. Agrícola e Florestal Santa Bārbara. Boletim Técnico, SIF. Viçosa, (1): 1-24. 
REZENDE, G.C.; W. SUITER Fọ; C.J. MENDES E T.S. de MORAES, 1981. Adubação de cepas de Eucalyptus grandis Hill ex (Maiden) na ocasião do primeiro corte. Circ. Téc. IPEF. Piracicaba, (129): 1-7, fev.

REZENDE, G.C.; J.C. GONCALVES e J.W. SIMÖES, 1983. Competicão entre fertilizantes fosfatados em plantios de eucalipto. In: Congresso Florestal Brasileiro, 40, Belo Horizonte. Anais. Silvicultura. São Paulo, (28): 451-454.

ROCHA, D., 1981. Estudos da dose, métodos e época de aplicacão de adubo em 2 ạ rotação de Eucalypius. In: Seminārio Florasa: Pesquisa florestal do Vale do Jequitinhonha, 40 , Itamarandiba. p.31-40.

SETZER, J., 1966. Atlas climático-ecológico do Estado de São Paulo. São Paulo, Comissão Interestadual da Bacia ParanáUruguai e Centrais Elétricas do Estado de São Paulo. 61p.

SILVA, J. de C., 1984. Espaçamentos em povoamentos florestais. Efeitos na produtividade, qualidade e na economicidade. Seminārio apresentado no Curso de Pós-Graduação à Disciplina "Formação e Manejo de Povoamentos Florestais". Piracicaba, 39p. [não publicado]. 
SILVA, J. de C., 1984. Parāmetros da densidade na qualidade da madeira. Seminārio apresentado no curso de Pōs-Graduacão à Disciplina "Qualidade da Madeira para Celulose e Papel". Piracicaba. 82p. [não publicado].

SIMÓES, J.W.; J. MASCARENHAS SOBRINHO; H.A. MELLO e H.T.Z. COUTO, 1970. A adubaça acelera o desenvolvimento inicial de plantacões de Pinus caribaea var. bahamensis. IPEF. Piracicaba, (1): 59-80.

SIMUES; J.W.; H.A. MELLO; N.B. LEITE; A. CIERO NETO, 1972. Resultados preliminares sobre a fertilizacão fosfatada no plantio de eucalipto. IPEF. Piracicaba, (5): 61-63.

SIMOES; J.W.; R.A.G. PEREIRA; O.K. TANAKA e R.M. POMPEU, 1972. Efeitos da ferramenta de corte sobre a regeneracão do euca1ipto. IPEF: Piracicaba. p.4.

SIMÖES, J.W., 1978. Manejo de florestas implantadas. In: Congresso Florestal Brasileiro, III. Manaus, 1978. Anais, São Paulo, SBS, V.2: 210-212. Edição Especial.

SIMOES, J.W.; R.M. BRANDI; N.B. LEITE; E.A.BALLONI, 1981. Formaç̃o, manejo e exploracão de florestas com espécies de räpido crescimento. Brasîlia, IBDF. $131 \mathrm{p}$. 
SIMOES, J.W., 1983. Implantação e Manejo de Florestas de Rāpido Crescimento. In: Simpōsio IUFRo: Em Melhoramento Genético e Produtividade de Espécies Florestais de Rāpido Crescimento. Anais. Silvilcutura. São Paulo, 1(29): 28-34 .

SIMOEES, J.W. e F. SPINA-FRANÇA, 1983. Produção de madeira em florestas energéticas sob diferentes prāticas silviculturais. Simpōsio: Energia da: Biomassá florestal. Convēnio CESP/IPEF. Relatório final, São Paulo. p.1-36. .

SOUZA, A.P.; R.M. DELLA LUCIA e G.C. REZENDE, 1979. Estudo da densidade básica da madeira de Eucalyptus microcorys $F$. Muell, cultivado na região de Dionísio, MG. Revista Arvore, $\underline{3}(1): 16-27$.

SOUZA, V.R. e L.E.G. BARRICHELLO, 1985. Características da madeira de duas procedências de Eucalyptus saligna. Relatório Técnico. Piracicaba, ESALQ/USP. Departamento de Silvicultura, Setor de Química, Celulose e Energia. 35p.

THORNTHWAITE, C.V. e J.R. MATHER, 1955. The water balance. Publications in climatology. Centerton, (8): 1-104. 
TUSET, R., 1981. Forestación para Produtores Agropecuarios. Editorial Hemisferio Sur, Montevideo. $368 \mathrm{p}$.

VAN DER SHOOTER, H., 1977. A importância da densidade da madeira na produtividade florestal. Comunicação técnica. PRODEPEF, Brasilia, (13): 1-8. 
.92 .

7. APÊNDICE 
Tabela 1. Anālise de variância para o crescimento em altura total média (m) aos 18 meses de idacie.

\begin{tabular}{lccc}
\hline CAUSA DA VARIACAO & G.L & Q.M & F \\
\hline Blocos & 2 & 0,055175781 & $0,043 \mathrm{~ns}$ \\
Tratamentos & 7 & 0,416156587 & $3,22 *^{*}$ \\
Reșĩduo & 14 & 0,129179227 & \\
\hline
\end{tabular}

Total

\section{3}

Média geral $=5,74 \mathrm{~m}$

Coeficiente de variação $=6,27 \%$

* = significativo ao nivel de $5 \%$

** = significativo ao nîvel de $1 \%$

$n s=$ não significativo

Tabela 2. Anālise de variância para o crescimento em altura total médịa (m) aos 29 meses de idade.

\begin{tabular}{lccc}
\hline CAUSA DA YARIACAO & G.L & Q.M & F \\
\hline Blocos & 2 & 1,3579407 & $5,17 *$ \\
Tratamentos & 7 & 2,3548366 & $8,97 * *$ \\
Resíduo & 14 & 0,2626223 & \\
\hline Total & 23 & & \\
\hline
\end{tabular}

Média geral: $7,98 \mathrm{~m} . \quad$ C.V. $=6,42 \%$ 
Tabela 3. Anālise de variāncia para o crescimento em altura tọtal média (m) aos 52 meses de idade.

\begin{tabular}{lrrl}
\hline CAUSA DA VARIACAO & G.L & Q.M & $\ldots F$ \\
\hline$\vdots$ & 2 & 2,6864319 & $3,31 \mathrm{~ns}$ \\
Blocos & 7 & 6,4478673 & $7,95 * *$ \\
Tratamentos & 14 & 0,8108090 & \\
Residuo & $6 \mathrm{~s}$ & & \\
\hline Total & & \\
\hline
\end{tabular}

Mëdia geral $=11,87 \mathrm{~m}$

C.V. $=7,58 \%$

Tabela 4. Anālise de variāncia para o crescimento em altura total média (m) aos 64 meses de idade.

\begin{tabular}{lrrl}
\hline CAUSA DA VARIACÁO & G.L & Q.M & F \\
\hline Blocos & 2 & 2,2494507 & $2,96 \mathrm{~ns}$ \\
Tratamentos & 7 & 6,8977574 & $9,06 * *$ \\
Residuo & 14 & 0,7609662 & \\
\hline
\end{tabular}

Total

23

Mèdia geral $=12,57 \mathrm{~m}$

C.V. $=6,94 \%$ 
Tabela 5. Anālise de variância para o crescimento em altura total mēdia (m) aos 76. meses de idade.

\begin{tabular}{l|rll}
\hline CAUSA DA VARIAÇ̃O & G.L & Q.M & F \\
\hline Blocos & 2 & 2,1271973 & $2,49 \mathrm{~ns}$ \\
Tratamentos & 7 & 7,9834798 & $9,36 * *$ \\
Resîduo & 14 & 0,8526199 & \\
\hline Total & 23 & & \\
\hline
\end{tabular}

Média geral $=13,38 \mathrm{~m}$

C.V. $=6,90 \%$

Tabela 6 . Anālise de variância para o crescimento em altura total mēdia (m) aos $\mathbf{8 5}$ meses de idacie.

\begin{tabular}{l|ccc}
\hline CAUSA DA VARIAÇAO & G.L & Q.M & $F$ \\
\hline Blocos & 2 & 1,3078003 & $1,43 \mathrm{~ns}$ \\
Tratamentos & 7 & 8,8220912 & 9,64 ** \\
Resíduo & 14 & 0,9151034 & \\
\hline Total & 23 & & \\
\hline
\end{tabular}

Mēdia geral $=13,62 \mathrm{~m}$

C.V. $=7,02 \%$ 
Tabela 7. Anālise de variância em fatorial para o crescimento em aitura to tal média. (m) aos 85 meses de idade.

CAUSA DA VARIACĀO

G.L - Q.M

Teste (F)

Desbrota (D)

3

15,9064128

$17,365 * *$

Adubação (A)

1

11,9516602

$13,048 * *$

(D) $\times(A)$

3

0,6945435

$0,758 \mathrm{~ns}$

Tratamentos

7

8,8220756

9,631 **

Blocos

2

1,3090820

1,429 ns

- Resīduo

14

0,9160109

Total

\section{3}

Média geral $=13,619 \mathrm{~m}$

C.V. $=7,03 \%$

Tabela 8. Anālise de variāncia para o crescimento em DAP médio dos brotos (cm) aos 29 meses de idade.

\begin{tabular}{lrrr}
\hline CAUSA DA VARIACA0 & G.L & Q.M & F \\
\hline Blocos & 2 & 0,6845245 & $5,21 *$ \\
Tratamentos & 7 & 3,1118992 & $23,71 * *$ \\
Resĩduo & 14 & 0,1312631 &
\end{tabular}

Total

23

Média geral $=5,77 \mathrm{~cm}$

C.V. $=6,28 \%$ 
Tabela 9. Anālise de variância para o crescimento em DAP médio dos brotos (cm) aos 52 meses de idade.

\begin{tabular}{lccc}
\hline CAUSA DA VARIACAO & G.L & Q.M & F \\
\hline Blocos & 2 & 0,6390381 & $2,87 . \mathrm{ns}$ \\
Trațamentos & 7 & 6,2820740 & $28,17 * *$ \\
Residuo & 14 & & \\
\hline Total & 25 & & \\
\hline
\end{tabular}

Média geral: $7,73 \mathrm{~cm}$

C.V. $=6,11 \%$

Tabela 10. Anālise de variāncia para o crescimento em DAP médio dos brotos $(\mathrm{cm})$ aos 64 meses de idade.

\begin{tabular}{l|crc}
\hline CAUSA DA VARIACAO & G.L & Q.M & $F$ \\
\hline Blocos & 2 & 0,8917694 & $2,71 \mathrm{~ns}$ \\
Tratamentos & 7 & 6,7209516 & $20,43 * *$ \\
Resĩduo & 14 & 0,3290085 & \\
\hline Total & 23 & & \\
\hline
\end{tabular}

Mëdia geral $=8,07 \mathrm{~cm}$

c.V. $=7,11 \%$ 
Tabela 11. Anālise de variância para o crescimento em DAP médio dos brotos $(\mathrm{cm})$ aos 76 meses de idade.

\begin{tabular}{lcrr}
\hline CAUSA DA VARIACAO & G.L & Q.M & F \\
\hline Blocos & 2 & 0,6340027 & $1,51 \mathrm{~ns}$ \\
Tratamentos & 7 & 7,6572237 & $18,29 * *$ \\
Residuo & 14 & $\ddots 0,4187627$ & \\
\hline
\end{tabular}

Total

23

Média geral $=8,16 \mathrm{~cm}$

C.V. $=7,94 \%$

Tabela 12. Anālise de variāncia para o crescimento em DAP médio dos brotos $(\mathrm{cm})$ aos 85 meses de idade.

\begin{tabular}{lrrr}
\hline CAUSA DA VARIACAO & G.L & Q.M & $F$ \\
\hline Blocos & 2 & 1,1264343 & $2,68 \mathrm{~ns}$ \\
Tratamentos & 7 & 8,8583955 & $21,05 * *$ \\
Resĩduo & 14 & 0,4208064 & $\ddots$ \\
\hline
\end{tabular}

Total

23

Média geral $=8,78 \mathrm{~cm}$

C.v. $=7,38 \%$ 
Tabela 13. Anālise de variância em fatorial para o crescimento em DAP mēdio dos brotos $(\mathrm{cm})$ aos 85 meses de idade.

\begin{tabular}{lccc}
\hline CAUSA DA VARIACAO & G.L & Q.M & TESTE (F) \\
\hline Desbrotado (D) & 3 & 18,7545573 & $44,422 * *$ \\
Adubação (A) & 1 & 3,9526367 & $9,362 * *$ \\
(D) x (A) & $j$ & 0,6003981 & $1,422 \mathrm{~ns}$ \\
\hline Tratamentos & 7 & 8,8596433 & $20,985 * *$ \\
Blocos & 2 & 1,1221924 & $2,658 \mathrm{~ns}$ \\
Resĩduo & 14 & 0,4221932 & \\
\hline Total & 23 & & \\
\hline
\end{tabular}

Média geral $=8,784 \mathrm{~cm} \quad$ C.V. $=7,40 \%$

Tabela 14. Anālise de variāncia para o crescimento da ārea basal dos brotos $\left(\mathrm{m}^{2} / \mathrm{ha}\right)$, aos 29 meses de idade.

\begin{tabular}{lcrr}
\hline CAUSA DA VARIACAO & G.L & Q.M & F \\
\hline Blocos & 2 & 3,2986145 & $1,23 \mathrm{~ns}$ \\
Tratamentos & 7 & 17,8211001 & $6,63 * *$ \\
Resïduo & 14 & 2,6883708 & \\
\hline Total & 23 & & \\
\hline
\end{tabular}

Média geral $=10,02 \mathrm{~m}^{2} / \mathrm{ha}$

C.V. $=16,36 \%$ 
Tabela 15. Anālise de variãncia para o crescimento da ārea basal dos brotos $\left(\mathrm{m}^{2} / \mathrm{ha}\right)$ aos 52 meses de idade.

\begin{tabular}{lrrr}
\hline CAUSA DA VARIAÇO & G.L & Q.M & F \\
\hline Blocos & 2 & 4,8483887 & 0,47 ns \\
Tratamentos & 7 & 39,5967553 & $3,87 *$ \\
Resíduo & 14 & 10.2327776 & \\
\hline Total & 23 & & \\
\hline
\end{tabular}

Média geral $=17,46 \mathrm{~m}^{2} / \mathrm{ha}$

C.V. $=18,32 \%$

Tabeta 16. Anālise de variância para o crescimento da ārea basal dos brotos $\left(\mathrm{m}^{2} / \mathrm{ha}\right)$ aos 64 meses de idade.

\begin{tabular}{lrrr}
\hline CAUSA DA VARIACÁO & G.L & Q.M & $F$ \\
\hline Blocos & 2 & 6,7921143 & 0,57 ns \\
Tratamentos & 7 & 39,8315662 & $3,35 *$ \\
Resĩduo & 14 & 11,8956891 & \\
\hline Total & 23 & & \\
\hline
\end{tabular}

Mèdia geral $=19,25 \mathrm{~m}^{2} / \mathrm{ha}$

C.V. $=17,91 \%$ 
Tabela 17. Anālise de variância para o crescimento da àrea basal dos brotos $\left(m^{2} / h a\right)$ aos 76 meses de idade.

\begin{tabular}{lrrr}
\hline CAUSA DA VARIACÁO & G.L & Q.M & F \\
\hline Blocos & 2 & 4,8604736 & $0,38 \mathrm{~ns}$ \\
Tratamentos & 7 & 37,5762881 & $2,97 *$ \\
Resĩduo & 14 & 12,6363347 & \\
\hline Total & 23 & & \\
\hline
\end{tabular}

Média geral $=19,40 \mathrm{~m}^{2} / \mathrm{ha}$

C.V. $=18,32 \%$

Tabela 18. Anālise de variãncia para o crescimento da ắrea basal dos brotos $\left(m^{2} / h a\right)$, aos 85 meses de idade.

\begin{tabular}{l|rrr}
\hline CAUSA DA VARIAÇAO & G.L & Q.M & $F$ \\
\hline Blocos & 2 & 9,0373535 & $0,57 \mathrm{~ns}$ \\
Tratamentos & 7 & 45,9491606 & $2,92 *$ \\
Resīduo & 14 & 15,7461403 & $\vdots$ \\
\hline Total & 23 & & \\
\hline
\end{tabular}

Mèdia geral $=22,08 \mathrm{~m}^{2} / \mathrm{ha}$

C.V. $=17,98 \%$ 
Tabela 19. Anālise de variâncịa em fatorial para o crescimento da ārea basal dos brotos $\left(m^{2} / h a\right)$, aos 85 meses de idade.

\begin{tabular}{lcrl}
\hline CAUSA DA VARIAÇAO & G.L & Q.M & TESTE (F) \\
\hline Desbrota (D) & 3 & 71,1318359 & $4,519 *$ \\
Adubação (A) & 1 & 94,4941406 & $6,003 *$ \\
(D) X (A) & 3 & 4,5091526 & $0,286 \mathrm{~ns}$ \\
\hline Tratamentos & 7 & 45,9167295 & $2,917 *$ \\
Blocos & .2 & 9,0556641 & $0,575 \mathrm{~ns}$ \\
Resĩduo & 14 & 15,7402132 &. \\
\hline
\end{tabular}

Total

23

Mèdia geral $=22,076 \mathrm{~m}^{2} / \mathrm{ha}$

C.V: $=17,97 \%$

Tabeia 20. Anālise de variância para o crescimento em volume cilindrico dos brotos $\left(\mathrm{m}^{3} / \mathrm{ha}\right)$ aos 29 meses de idade.

\begin{tabular}{lcrl}
\hline CAUSA DA VARIACAO & G.L & G.M & \multicolumn{1}{c}{ F } \\
\hline Blocos & 2 & 574,42578 & $1,54 \mathrm{~ns}$ \\
Tratamentos & 7 & 1561,54594 & $4,18 *$ \\
Resĩduo & 14 & 373,30681 & \\
\hline Total & 23 & & \\
\hline
\end{tabular}

Mēdia geral: $94,34 \mathrm{~m}^{3} / \mathrm{ha}$

C.V. $=20,48 \%$ 
Tabela 21. Anālise de variação para o crescimento em volume cilíndrico dos brotos $\left(\mathrm{m}^{3} / \mathrm{ha}\right)$ aos 52 meses de idade.

\begin{tabular}{lccc}
\hline CAUSA DA VARIAÇAO & G.L & Q.M & F \\
\hline Blocos & 2 & 4601,56 & $1,11 \mathrm{~ns}$ \\
Tratamentos & 7 & 9492,94 & $2,30 \mathrm{~ns}$ \\
Resíduo & 14 & 4131,76 & \\
\hline Total & 23 & & \\
\hline
\end{tabular}

Média geral $=254,88 \mathrm{~m}^{3} / \mathrm{ha}$

C.V. $=25,22 \%$

Tabela 22. Anālise de variação para o crescimento em volume cilîndrico dos brotos $\left(\mathrm{m}^{3} / \mathrm{ha}\right)$ aos 64 meses de idade.

CAUSA DA VARIAÇÃO

G.L

Q.M.

$\mathrm{F}$

\begin{tabular}{lrrl}
\hline Blocos & 2 & 5644,19 & $1,04 \mathrm{~ns}$ \\
Tratamentos & 7 & 11303,43 & $2,08 \mathrm{~ns}$ \\
Resĩduo & 14 & 5436,23 & \\
\hline
\end{tabular}

Total

23

Média geral $=392,18 \mathrm{~m}^{3} / \mathrm{ha}$

C.V. $=24,40 \%$ 
Tabela 23. Anālise de variação para o crescimento em volume ciliñdrico dos brotos $\left(\mathrm{m}^{3} / \mathrm{ha}\right)$ aos 76 meses de idade.

\begin{tabular}{lrrr}
\hline CAUSA DA VARIACAO & G.L. & Q.14 & F \\
\hline Blocos & 2 & 5700,69 & $0,96 \mathrm{~ns}$ \\
Tratamentos & 7 & 12077,01 & $2,04 \mathrm{~ns}$ \\
Resīduo & 14 & 5933,26 & \\
\hline Total & 23 & & \\
\hline
\end{tabular}

Média geral $=325,01 \mathrm{~m}^{3} / \mathrm{ha}$

C.V. $=23,70 \%$

Tabela 24. Anälise de variação para o crescimento em volume cilíndrico dos brotos $\left(\mathrm{m}^{3} / \mathrm{ha}\right)$ aos 85 meses de idade.

\begin{tabular}{lrrr}
\hline CAUSA DA VARIACÁ & G.L & Q.M & F \\
\hline Blocos & 2 & 6133,87 & $0,80 \mathrm{~ns}$ \\
Tratamentos & 7 & 14608,00 & $1,91 \mathrm{~ns}$ \\
Resĩduo & 14 & 7650,75 & \\
\hline
\end{tabular}

Total

23

Média geral $=374,76 \mathrm{~m}^{3} / \mathrm{ha}$

C.V. $=23,34 \%$ 
Tabela 25. Anālise de variância em fatorial para o crescimento em volume cilindrico dos brotos ( $\mathrm{m}^{3} / \mathrm{ha}$ ) às 85 meses de idade.

\begin{tabular}{lccc}
\hline CAUSA DA VARIAÇAO & G.L & Q.M & TESTE (F) \\
\hline Desbrota (D) & 3 & 13983,83 & $1,828 \mathrm{~ns}$ \\
Adubação (A) & 1 & 53449,75 & $6,986 *$ \\
(D) X (A) & 3 & $.2285,58$ & $0,299 \mathrm{~ns}$ \\
\hline Tratamentos & 7 & 14608,28 & $1,909 \mathrm{~ns}$ \\
Blocos & 2 & 6136,38 & $0,802 \mathrm{~ns}$ \\
Resĩduo & 14 & 7650,62 & \\
\hline Total & ćs & & \\
\hline
\end{tabular}

Média geral: $374,758 \mathrm{~m}^{3} / \mathrm{ha}$

C.V. $=23,34 \%$

Tabela 26 - Anālise da variância das falhas das touças de Eucalyptus saligna Smith, aos 85 meses de idade, com os dados transformados em arco sen $\checkmark$ no falhas $+0,5$.

\begin{tabular}{lrrr}
\hline CAUSA DA VARIACAO & G.L & Q.M & F \\
\hline Blocos & 2 & 18,4355469 & $1,41 \mathrm{~ns}$ \\
Tratamentos & 7 & 15,5131603 & $1,19 \mathrm{~ns}$ \\
Residuo & 14 & 13,0444757 & \\
\hline Total & 23 & & \\
\hline
\end{tabular}

Média geral $=32,21 \%$

C.V. $=10,87 \%$ 


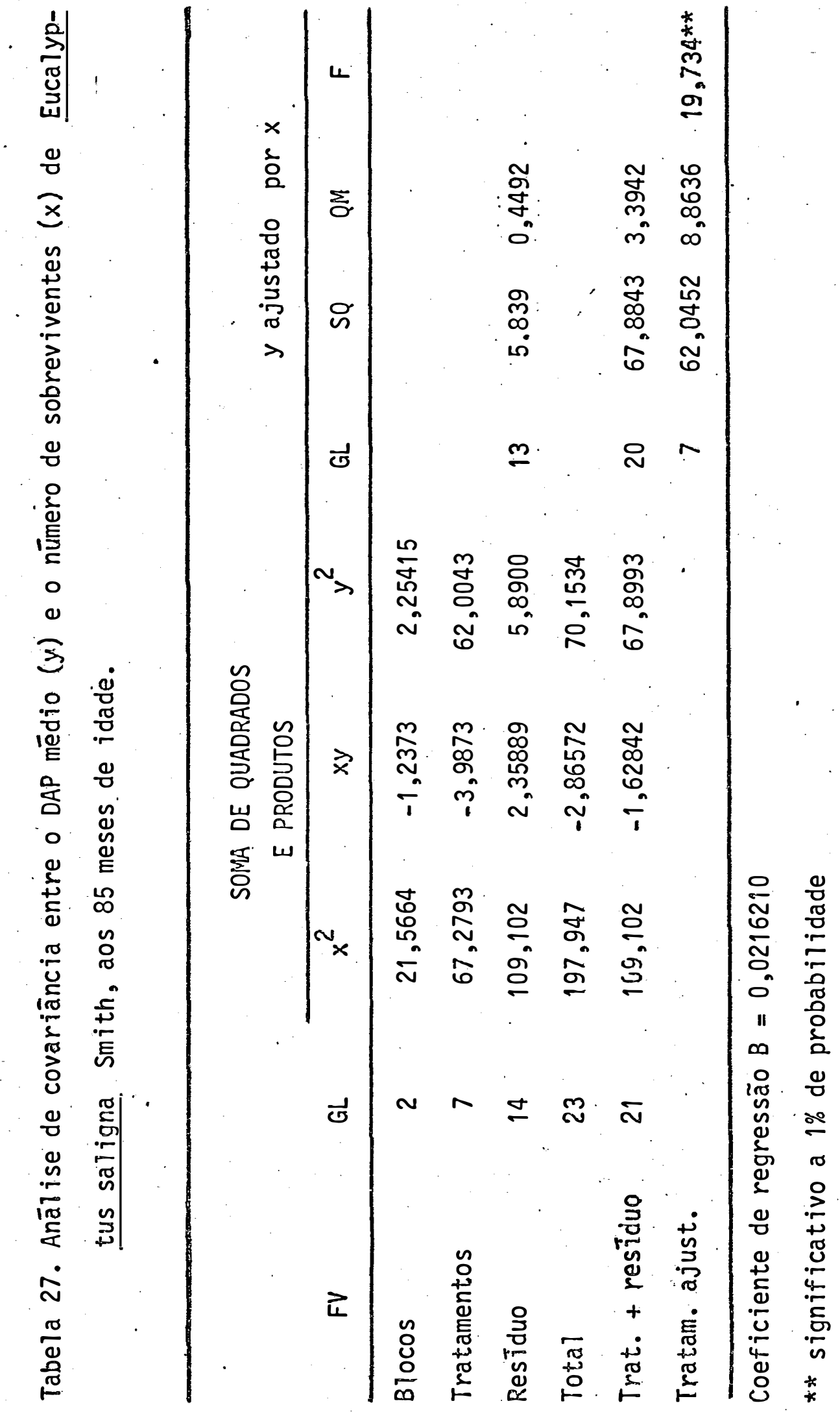




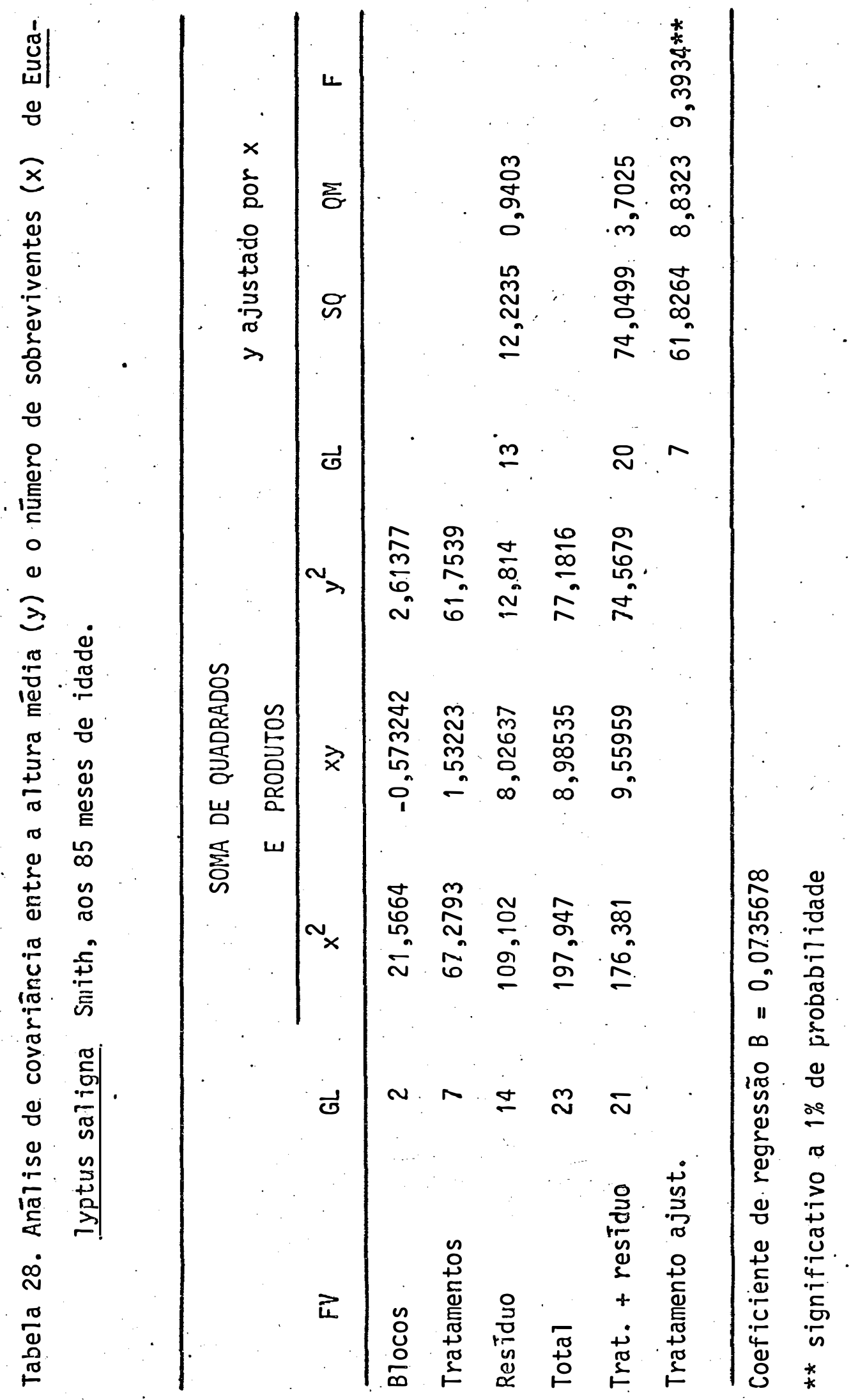




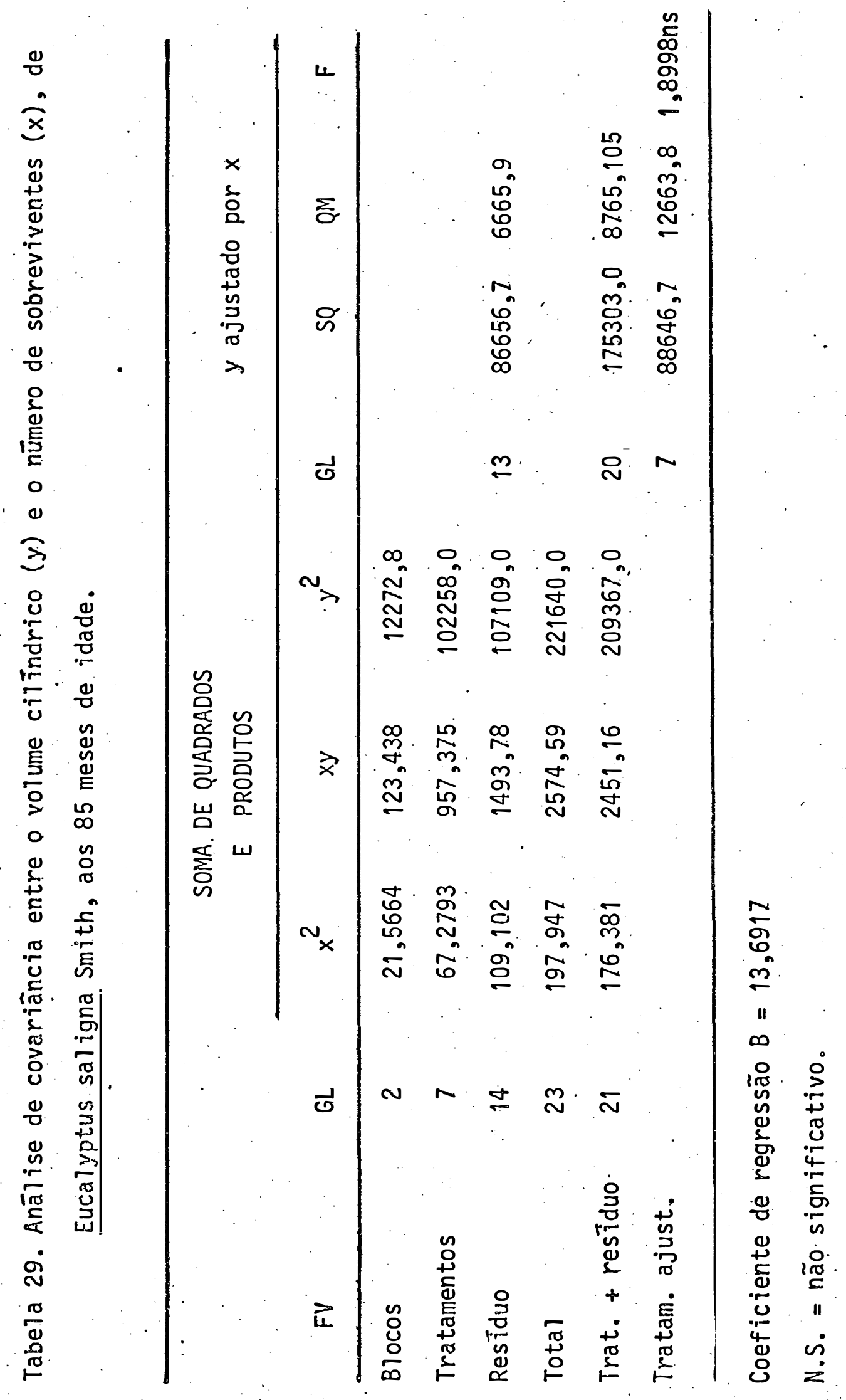


Tabela 30. Anālise de variância àos dados de porcentagem de casca dos bro tos das touças de Eucalyptus saligna Smith, aos 85 meses de idade.

\begin{tabular}{lcccc}
\hline CAUSA DA VARIACÁ̃ & G.L & Q.M & F & \\
\hline Blocos & 2 & 10,9191895 & $3,23 \mathrm{~ns}$ \\
Tratamentos & 7 & 4,2245164 & $1,25 \mathrm{~ns}$ \\
Resĩduo & 14 & 3,3785299 & $\ddots$ \\
\hline rotal & 23 & & \\
\hline
\end{tabular}

Mēdia geral $=27,01 \%$

C.V. $=6,81 \%$

Tabela 31. Anālise de variāncia dos dạdos de volume de madeira empī hada (estereo/ha) de brotos de touças de Eucalyptus saligna. Smith, aos 85 meses de idade.

\begin{tabular}{lccc}
\hline CAUSA DA VARIACÃ & G.L & Q.M & F \\
\hline Blocos & 2 & 1,4951782 & $0,98 \mathrm{~ns}$ \\
Tratamentos & 7 & 4,1545497 & $2,72 \mathrm{~ns}$ \\
Resíduo & 14 & 1,5278662 & \\
\hline
\end{tabular}

Total

23

Mëdia geral $=6,20$

C.V. $=19,92 \%$ 
Tabela 32. Anālise de variância dos dados de densidade mëdia $\left(\mathrm{g} / \mathrm{cm}^{3}\right)$ dos brotos de touças de Eucalyptus saligna Smith, aos 85 meses de idade.

\begin{tabular}{lccc}
\hline CAUSA DA VARIACSAO & G.L & Q.M & F \\
\hline Blocos & 2 & 0,000040889 & $0,65 \mathrm{~ns}$ \\
Tratamentos & $Z$ & 0,000032221 & $0,52 \mathrm{~ns}$ \\
Residuo & 14 & 0,000062485 & \\
\hline Total & 23 & & \\
\hline
\end{tabular}

Média geral $=0,52$

C.V. $=1,53 \%$

Tabela 33. Anālise de variāncia do peso de madeira seca em peso ( $\mathrm{kg} / \mathrm{ha})$ dos brotos das touças de Eucalyptus saligna Smith, aos 85 meses de idade.

\begin{tabular}{lccc}
\hline CAUSA DA VARIACAO & G.L & Q.M & $F$ \\
\hline Blocos & 2 & 715493376,00 & \\
Tratamentos & 7 & 1105919024,76 & \\
Resíduo & 14 & 537770069,33 \\
\hline Totai & 23 & & \\
\hline Média geral $=105509,51$ & & C.V. $=21,90 \%$ &
\end{tabular}

